\title{
KONSEP KHILAFAH MENURUT SAYYID QUTHB DAN TAQIYUDDIN AL-NABHANI DALAM PERSPEKTIF SYIASYAH SYAR'IYYAH
}

\author{
Nurhadi \& Mawardi Dalimunthe \\ Sekolah Tinggi Agama Islam (STAI) Al-Azhar Pekanbaru Riau \\ alhadijurnal@gmail.com; Mawardidalimunthe@gmail.com
}

\begin{abstract}
The purpose of this study is to find out the concept of kbilafah according to Sayyid Quthub and Taqiyuddin al-Nabhani, differences and legal basis. This study is a library model, with primary data sources, the Zhilalal-Qur'anic Tafseer and Nizham Al-Hukmi Fi Al-Islam and qualitative descriptive analysis methods. The result is the thought of the concept of khilafah according to sayyid Quthub: 1). The concept of the ruler / caliph, that who becomes the ruler of the choice of the Muslims, acts in absolute freedom, but that person gets the authority because he constantly applies the law of Allah Almighty. 2). The Islamic government system, the Supra Nasional government (the unity of the entire Islamic world). 3). The pillars of his Islamic government: a). Justice of the ruler; b). People's obedience; $c$ ). Consultation between the people and the authorities. Thought of the concept of the Caliphate according to Taqiyuddin Al-Nabhani: 1). The concept of the ruler / caliph is a person who represents the Ummah in government affairs and power and in applying syara 'laws. 2). The system of government is khilafah. 3). The pillars of his Islamic government: a). Sovereignty in the hands of syara '; b). Power of the people; c). To appoint a legal Caliph fardlu for all Muslims; d). Only Khailfah has the right to carry out tabanni (adoption) against syara 'laws; e) The Caliph has the right to make constitutions and all other laws. The differences in the concept of kbilafah are both: 1). According to Sayyid Quthub, if the ruler fails, then the ruler can be dismissed if the Muslims are no longer satisfied with bim. This statement gives a signal that the people get rid of the rulers who no longer fulfill their functions (zhalim rulers). It is different from the opinion of Taqiyuddin al-Nabhani. An Amir al-mu'minin (Khalifah), even though he is responsible before the people and his representatives, but the people and their representatives are not entitled to dismiss him. Nor will the Caliph be dismissed, except when deviating from Shara law. The one who determined the dismissal was only the Marhalim court. 2). The system of Islamic government according to Sayyid Quthub does not question any system of government in accordance with the system of conditions of society, but this government is characterized by respect for the supremacy of Islamic law (shari'ab). Whereas According to Taqiyuddin Al-Nabhani that the system of Islamic government is khilafah. 3). The pillars of Islamic government according to Sayyid Quthub and Taqiyyuddin al-Nabhani, points three parts $a$ and $b$ at the above conclusions are: 1). Sayyid Quthub: a). Justice of the ruler; b). People's obedience; c). Consultation between the people and the authorities. 2). Taqiyyuddin alNabhani: a). Sovereignty in the hands of syara; b). Power of the people; c). To appoint a legal Caliph fardlu for all Muslims; d). Only Khailfah has the right to do tabanni (adoption) against the laws of shara; e). The Caliph has the right to make constitutions and all other laws. The legal bases for determining the Caliphate according to both: 1). The legal basis for the establishment of the Caliphate according to Sayyid Quthub: 1). Ruler, Qur'an Surah (2) al-Baqarah verse 30; 2). Islamic Government System, Qur'an Surah (24) an-Nur verse 55; 3). Pillars of Islamic Government, Qur'an Surah (4) an-Nisa 'verse 58. 2). The legal basis for the establishment of the Caliphate according to Taqiyyuddin al-Nabhani: 1). Ruler, hadith of Muslim history from Abu Said Al khudri, Hadith no. 1853 and Muslims from Abdullah Bin Amru Bin Ash, Hadith no. 1844; 2). Islamic Government System, Al-Qur'an surah an-Nisa '(4) verse 59, an-
\end{abstract}

PALAPA : Jurnal Studi Keislaman dan Ilmu Pendidikan

Volume 8, Nomor 2, November 2020; p-ISSN 2338-2325; e-ISSN 2540-9697; 244-284

https://ejournal.stitpn.ac.id/index.php/palapa 
Nisa' (4) verse 65. Muslim, sabeeh Muslim, volumes, 3 pp., 1459 and 1480; 3). Islamic Pillars of Government al-Qur'an surah An-Nisa (3) verse 65, and Surah An-Nisa (3) verses': 5.

Keywords: Concept, Caliphate, Perspective, Syiasyab Syar'iyyah

\begin{abstract}
Abstrak : Tujuan Penelitian ini untuk mengetahui konsep khilafah menurut Sayyid Quthub dan Taqiyuddin al-Nabhani, perbedaan dan dasar hukumnya. Penelitian ini model kepustakaan, dengan sumber data primer kitab Tafsir Fi Zhilalal-Qur an dan Nizham Al-Hukmi Fi Al-Islam dan metode analisis deskriptif kualitatif. Hasilnya Pemikiran konsep khilafah menurut sayyid Quthub: 1). Konsep penguasa/khalifah, bahwa yang menjadi penguasa pilihan kaum muslimin, bertindak dalam kebebasan mutlak, namun orang tersebut mendapat otoritas karena terus menerus menerapkan hukum Allah swt. 2). Sistem pemerintahan Islamnya, pemerintahan Supra Nasional (kesatuan seluruh dunia Islam). 3). Pilar-pilar pemerintahan Islamnya: a). Keadilan penguasa; b). Ketaatan rakyat; c). Permusyawaratan antara rakyat dengan penguasa. Pemikiran Konsep khilafah menurut Taqiyuddin Al-Nabhani: 1). Konsep penguasa/khalifah adalah orang yang mewakili ummah dalam urusan pemerintahan dan kekuasaan dan dalam melaksanakan undang-undang syara'. 2). Sistem pemerintahannya khilafah. 3). Pilar-pilar pemerintahan Islamnya: a). Kedaulatan di tangan syara'; b). Kekuasaan milik umat; c). Untuk melantik seorang khalifah undang-undang adalah fardlu bagi semua umat Islam; d). Hanya Khailfah yang berhak melakukan tabanni (penerimaan) undang-undang syara'; e) Khalifah berhak membuat perlembagaan dan semua undang-undang lain. Perbedaan konsep khilafah keduanya adalah: 1). Menurut Sayyid Quthub, apabila penguasa gagal, maka penguasa tersebut dapat dipecat bila umat muslimin tidak lagi puas dengannya. Pernyataan ini memberikan isyarat supaya umat menyingkirkan penguasa yang tidak lagi memenuhi fungsinya (penguasa zhalim). Lain halnya dengan pendapat Taqiyuddin al-Nabhani. Seorang Amirul mukminin (Khalifah), meskipun bertanggung jawab dihadapan umat dan wakil-wakilnya, namun umat dan wakilnya tidak berhak memecatnya. Khalifah juga tidak akan diberhentikan, kecuali dia menyimpang dari hukum syara '. Untuk menentukan pemecatannya, hanya pengadilan Mazhalim. 2). Menurut Sayyid Quthub, sistem pemerintahan Islam tidak mempersoalkan sistem pemerintahan mana pun sesuai dengan sistem kondisi sosial, tetapi pemerintahan ini ditandai dengan penghormatan terhadap superemasi undang-undang Islam (syari'ah). Sementara itu, menurut Taqiyuddin Al-Nabhani, sistem pemerintahan Islam adalah khalifah. 3). Pilar-pilar pemerintahan islam menurut Sayyid Quthub dan Taqiyyuddin al-Nabhani, poin tiga bagian a dan b pada kesimpulan diatas ialah: 1). Sayyid Quthub: a). Keadilan penguasa; b). Ketaatan rakyat; c). Permusyawaratan antara rakyat dengan penguasa. 2). Taqiyyuddin al-Nabhani: a). Kedaulatan di tangan syara; b). Kekuasaan milik umat; c). Untuk melantik seorang khalifah undang-undang adalah fardlu bagi semua umat Islam; d). Hanya Khailfah yang berhak membuat tabanni (pemakaian) undang-undang syara; e). Khalifah berhak membuat perlembagaan dan semua undang-undang lain. Dasar-dasar hukum penetapan khilafah menurut keduanya: 1). Dasar-dasar hukum penetapan khilafah menurut Sayyid Quthub: 1). Penguasa, Qur'an Surah (2) al-Baqarah ayat 30; 2). Sistem Pemerintahan Islam, Qur'an Surah (24) an-Nur ayat 55; 3). Pilar-Pilar Pemerintahan Islam, Qur'an Surah (4) an-Nisa' ayat 58. 2). Dasar-dasar hukum penetapan khilafah menurut Taqiyyuddin al-Nabhani: 1). Penguasa, hadis riwayat Muslim dari Abu Said Al khudri, Hadits no. 1853 dan Muslim dari Abdullah Bin Amru Bin Ash , Hadis no. 1844; 2). Sistem Pemerintahan Islam, al-Qur'an surah an-Nisa'(4) ayat 59, an-Nisa'(4) ayat 65. Muslim, shahih Muslim,jilid, 3 hlm, 1459 dan 1480; 3). Pilar-Pilar Pemerintahan Islam al-Qur'an surah An-Nisa(3) ayat 65, dan Surah An-Nisa (3) ayat': 5.
\end{abstract}

Kata Kunci: Konsep, Khilafah, Perspektif, Syiasyah Syar'iyyah 


\section{PENDAHULUAN}

Islam adalah agama rahmat. ${ }^{1}$ Agama yang sempurna dalam arti mengatur seluruh interaksi yang terjadi antara manusia dengan Allah, berkenaan tentang ibadah, manusia dengan sesama manusia, berkenaan tentang mu'amalah termasuk didalamnya tentang masalah pemerintahan, manusia dengan dirinya sendiri, berkenaan ahlak, makanan, minuman. ${ }^{2}$ Islam telah diturunkan kepada Rasulullah Saw, sejak empat belas abad yang telah lalu. Untuk memberikan kepada manusia penyelesaian secara menyeluruh atas semua permasalahan yang akan dihadapi oleh manusia. Maka islam adalah solusi dalam persoalan. Termasuk diantaranya adalah persoalan tentang masalah khilafah. Dan itu dijelaskan Allah dalam firmannya: al-Baqarah (2): $3 .^{3}$

Semenjak Rasulullah wafat, masa kepemimpinan khilafah mulai berlaku yaitu pada khalifah yang pertama adalah Abubakar Ash-Shiddik, sampai kepada masa khilafah Turki Utsmani di Istanbul (Turki). yang dipandang sebagai khilafah dan pemerintahan Islam sedunia yang terakhir.

Karena pada abad 18 paradigma pemikiran politik dari para pemikir Islam mengalami perubahan seiring dengan perkembangan politik dunia Islam mengalami kemunduran. Eksitensi pemerintahan model khilafah ini tidak dapat dipertahankan oleh ummat Islam. Ia berakhir tanggal 3 Maret 1924 oleh Musthafa kemal Attartuk (1881-1938 M) ${ }^{4}$ pada masa itu muncul keinginan untuk mengganti konsep politik Islam system negara kesatuan (khilafah) dengan konsep politik Barat system Negara bangsa (nation state). Perubahan pemikiran politik itu terjadi karena upaya responsive para pemikir Islam dalam menjawab problema yang berkembang dalam dunia Islam. Ketika itu, kemunduran politik disebabkan oleh disintegrasi politik dengan melemahnya otoritas pemerintahan pusat dan munculnya semi otonomi di berbagai daerah, disertai dengan terjadinya dislokasi social, memburuknya situasi ekonomi akibat persaingan dagang dengan Eropa, serta merosotnya spritualitas dan moralitas masyarakat, terutama penguasa. $^{5}$

Kemunduran dunia Islam tidak hanya berdampak di pusat, tetapi juga di wilayah-wilayah Islam. Dunia Islam sudah mulai merasakan ketinggalan di bidang ekonomi dan militer dari negara-negara Barat. Secara berlahan dunia Islam bergeser posisi dari ofensif (ekspansi memperluas wilayah kekuasaan) menjadi defense (bertahan 
membenah diri). Pada akhir abad 19 M, penetrasi kekuasaan Barat ke dalam dunia Islam mencapai puncaknya, dari Maroko di ujung barat sampai Indonesia di ujung timur. Kehadiran militer dan ekonomi Barat di dunia Islam cenderung berbentuk dominasi politik seperti penjajahan, secara langsung atau tidak langsung. Khilafah Usmani terpaksa bersikap defensive menghadapi tekananmiliter dan ekonomi negara-negara Barat.

Realita tersebut melatar belakangi munculnya politik Islam kontemporer yang terpolarisasi tiga aliran pemikiran politik. ${ }^{6}$ Kelompok pertama, memahami bahawa Islam tidak dianggap hanya dalam pengertian Barat, yang hanya mementingkan hubungan antara manusia dan Tuhan. Sebaliknya, Islam adalah agama yang sempurna dan lengkap dengan peraturan untuk semua aspek kehidupan manusia, termasuk urusan negara. Tetapi juga menolak anggapan bahawa dalam Islam ada peraturan untuk sistem negara, tetapi apa yang ada adalah seperangkat nilai, etika untuk kehidupan bernegara. ${ }^{7}$ Tokoh-tokoh aliran ini antara lain, Hasan al-Banna, Sayyid Quthub, Muhammad Rasyid Ridha, Taqiyuddin Al-Nabhani dan Maulana A. Al- Maududi.; kelompok kedua, memahami bahwa Islam dipandang sebagai agama dalam pengertian Barat yaitu agama hanya dijadikan sebagai moral dan ritual semata, yang tidak ada hubungannya dengan urusan dunia dan kenegaraan. Barat memahami bahwa agama hanya urusan privat dan bukan urusan public. Oleh karena itu, keduanya terpisah dan tidak ada hubungan sama sekali. Kelompok ini berpandangan bahwa Nabi Muhammad hanya dipandang sebagai Rasul penyampai risalah Ilahi, seperti Rasul lainnya dan tidak pernah dimaksudkan untuk mendirikan dan mengepalai satu negara. Tokoh-tokoh aliran ini antara lain Ali Abdul Rariq dan Thaha Husein; kelompok ketiga, memahami bahwa Islam bukanlah agama yang serba lengkap, termasuk di dalamnya memiliki sistim kenegaraan. Kelompok ini menolak anggapan bahwa Islam pengertian Barat, yang hanya mengatur hubungan antara manusia dengan Tuhan. Menurut kelompok ini, tidak mengatur sistim kenegaraan, melainkan mengatur tata nilai etika dalam kehidupan negara. Kelompok ini berpandangan bahwa Islam hanya mengatur prinsip moral dan akhlak. Tokoh-tokoh aliran ini antara lain Muhammad Husein Haikal. ${ }^{8}$

Sekalipun kekhalifaan Islam telah dihapuskan, masih saja muncul usaha untuk menghidupkan kembali kekhalifaan Islam. Usaha tersebut dilakukan 0leh Raja Fuad I, (Raja Mesir). Usaha Raja Fuad ini menyebabkan terjadinya krisis antara pihak istana 
dengan Partai al-Ahrar ad-Dusturiyyan pada tahun1924. Raja Fuad I berupaya memperjuangkan kembalinya negara khilafah. Sedangkan partai al-Abrar ad-Dusturiyyan menentang kembalinya negara khilafah. ${ }^{9}$ Akan tetapi sampai sekarang ini usaha-usaha untuk menciptakan khilafah itu terus bergulir terutama dari kalangan HTI (Hizb-alTahrir Indonesia). dan ini seharusnya di dukung oleh ummat Islam, terutama Indonesia yang mayoritas ummat Islam terbesar di dunia. Dan melihat sistem pemerintahan sekarang ini sangat jauh dari nilai-nilai keislaman. Padahal kita mengetahui bahwa manusia diciptakan adalah sebagai khalifah. Baik khalifah sebagai 'Abid maupun khalifah sebagai pemimpin dalam pemerintahan.

Al-Qur'an diturunkan Allah untuk menjelaskan segala sesuatu tidak ada yang membatasi, sehingga dikatakan bahwa Islam adalah agama yang sempurna. ${ }^{10}$ Maksudnya setiap permasalahan yang terjadi di dunia ini semuanya ada penjelasannya dalam AlQur'an. Allah menurunkan aturannya untuk menjadi petunjuk bagi manusia agar manusia tidak memperturutkan hawa nafsunya, sekaligus sebagai kabar gembira bagi orang-orang yang taat, patuh dan berserah diri.

Wujud dari kesempurnaan itu, Islam tidak hanya masalah hubungan manusia dengan Tuhannya. Tapi Islam juga mengatur dan menyelesaikan permasalahan diseputar hubungan manusia dengan dirinya sendiri maupuan dengan sesamanya. ${ }^{11}$

Hubungan manusia dengan penciptanya mencakup dalam perkara aqidah dan ibadah. Hubungan manusia dengan dirinya tercakup dalam muamalah dan akhlak, makanan, minuman, dan pakaian. Sedangkan wujud dari aturan Islam yang mengatur interaksi sosial, tercakup dalam muamalah dan uqubat. ${ }^{12}$

Dalam perkara mua'malah mencakup sistem pemerintahan, sistem ekonomi, sistem sosial, sistem pergaulan, sistem pendidikan dan lainnya. ${ }^{13}$ Dalam sistem pemerintahan yang termasuk dalam cakupannya adalah tentangbentuk negara dan sekaligus struktur pemerintahannya.

Banyak nash syara' baik al-Qur'an maupun al-Sunnah yang memerintahkan kaum muslimin untuk merealisasikan adanya negara Islam dalam bentuk Khilafah, antara lain An-nisa'(4) 59, yang artinya: 'Hai orang-orang yang beriman, taatilah Allab dan taatilah Rasul Nya, dan Ulil amri (pemimpin) di antara kamu”." ${ }^{14}$ 
Ayat ini adalah perintah mentaati penguasa (pemimpin), dan untuk memiliki pemerintahan. Sebab Allah swt, tidak memerintahkan taat pada sesuatu yang tidak ada. Jadi, adanya penguasa dalam satu negara adalah suatu keharusan. Dan perintah Allah untuk mentaati Ulil 'amri adalah juga perintah Allah untuk mengangkat mereka. ${ }^{15}$

Allah mewajibkan umat Islam untuk menghukumi setiap permasalahan yang terjadi di tengah-tengah kehidupan mereka dengan hukum-hukum syariat Islam. Allah memerintahkan Rasulullah untuk mengurus urusan kaum muslimin dengan apa yang diturunkan Allah kepadanya. Selain itu masih banyak lagi hukum-hukum Islam yang tidak mungkin bisa dilaksanakan kecuali dengan adanya Negara Islam yaitu Khilafah. Hukum adanya negara Islam yaitu khilafah adalah diwajibkan, sebagai sebahagian dari hukum, wajib melaksanakan hudud. Dalam Qaidah ushul fikih disebutkan:

$$
\text { ما لا يتم الو اجب الا به فهو واجب }
$$

Artinya: "Kewajiban tidak dapat dilaksanakan dengan sempurna, kecuali jikea ada yang lain, maka sesuatu itu menjadi wajib juga". ${ }^{16}$

Suatu kewajiban tidak terlaksana dengan sempurna tanpa adanya sesuaatu yang dapat melaksanakannya kewajiban-kewajiban tersebut. Hukum sesuatu itu adalah wajib. Karena tanpa adanya sesuatu yang dimaksud, kewajiban tidak terlaksana dengan sempurna.

Dari sejarah kemunduran umat Islam, didukung dengan nash-nash di atas muncullah para pemikir politik Islam (ulama Tenporer), antara lain Sayyid Quthub dan Taqiyuddin al-Nabhani.

Berdasarkan uraian diatas, maka yang menjadi pokok masalahnya dapat dirumuskan sebagai berikut : 1). Bagaimana konsep khilafah menurut Sayyid Quthb dan Taqiyuddin Al-Nabhani tentang penguasa, sistem pemerintahan islam, pilar-pilar pemerintahan islam?; 2). Apa perbedaan konsep khilafah menurut Sayyid Quthub dengan Taqiyyuddin al-Nabhani (Hizbuttahrir) tentang penguasa, sistem pemerintahan islam, pilar-pilar pemerintahan islam?; 3). Apa dasar-dasar hukum penetapan khilafah menurut Sayyid Quthub dan Taqiyyuddin al-Nabhani tentang penguasa, sistem pemerintahan islam, pilar-pilar pemerintahan islam? 


\section{METODE PENELTIAN}

Penelitian ini didesain dalam bentuk penelitian kepustakaan (library research). Penelitian kepustakaan dengan menelaah berbagai literatur yang berkaitan dengan topik penelitian berdasarkan kerangka yang jelas dan relevan.

Sumber data dalam penelitian ini ada dua kelompok yaitu sumber data primer dan sumber data sekunder.

a) Sumber Data Primer adalah tulisan Sayyid Quthb sendiri yang tersebar di beberapa hasil karyanya dan ditelusuri secara lebih cermat, khususnya dalam tafsir Fi Zhilalal-Qur`an tentang ayat-ayat yang berkaitan dengan konsep khilafah, terutama tafsir Sayyid Qutub tentang konsep khilafah yang diformulasikannya. Bukunya yang lain yaitu Fî al-Tarikh: Fikratun wa Minhajuh, alih bahasa Nabhan Husein, Konsepsi Sejarah dalam Islam, Keadilan Sosial dalam Islam, Petunjuk Jalan dan Islam dan Perdamaian Dunia. Dan karya-karya tulisan Taqiyuddin al-Nabhani dalam kitab: Nizham Al-Hukmi Fi Al-Islam, alDaulah Islamiyah, Al-Syakhsiyah Al-Islamiyah, Muqaddimah al-Dustur, Nizham al-Islam.

b) Sumber Data Sekunder adalah tulisan orang lain tentang pemikiran Sayyid Quthb dan Taqiyuddin al-Nabhani terutama yang berkaitan dengan pemikiran tentang konsep khilafah, pemikiran politik Islam dan bentuk negara.

Teknik pengumpulan data dalam penelitian ini dari data primer dan skunder, dalam kajian ini diperoleh rnelalui penelaan kepustakaan dengan cara mencari dan menemukan literatur tentang pemikrian politik Islam Sayyid Quthb dan pemikiran politik Islam Taqiyuddin tentang khilafah, serta tulisan-tulisan yang menulis tentang pemikiran Sayyid Quthub dan Taqiyuddin al-Nabhani, kemudian dibaca dan diteliti serta disusun sesuai dengan sumber data, baik yang primer maupun sekunder. Setelah dikumpul dan diklasifikasikan sesuai dengan topik bahasan.

Adapun metode analisis data yang digunakan oleh penulis dalam menganalisa data adalah menggunakan teknik diskriptik analitik, yaitu dengan jalan mengumpulkan data dan menjelaskan pernikiran Sayyid Quthb danTaqiyuddin al-Nabhani, kemudian dianalisis sedalam mungkin dan disusun sebagaimana yang diatur dalam penulisan tesis. 


\section{PEMBAHASAN DAN HASIL}

\section{Konsep Pemikiran Sayyid Quthub}

\section{Tentang Penguasa (Khalifah)}

Menurut Sayyid Quthb bahwa orang yang menjadi penguasa (Khalifah) karena pilihan sempurna kaum muslimin, yang bertindak dalam kebebasan mutlak, namun orang tersebut mendapat otoritas karena terus menerus menerapkan hukum Tuhan. Kalau hal ini gagal, maka penguasa tersebut dapat dipecat bila umat muslimin tidak lagi puas dengannya. Pernyataan ini memberikan isyarat supaya umat menyingkirkan penguasa yang tidak lagi memenuhi fungsinya (penguasa zhalim).

Lain halnya dengan pendapat Taqiyuddin al-Nabhani. Seorang Amirul mukminin (Khalifah), meskipun bertanggung jawab dihadapan umat dan wakil-wakilnya, namun umat dan wakilnya tidak berhak untuk memberhentikannya. Khalifah juga tidak akan diberhentikan, kecuali dia menyimpang dari hukum syara '. Untuk menentukan pemecatannya, hanya pengadilan Mazhalim. ${ }^{17}$

Dalam siyasah syar'iyyah, masalah kepemimpinan merupakan unsur yang signipikan dalam pemerintahan Islam. Kepemimpinan dalam Islam sebenarnya bukan satu posisi yang harus diperebutkan, karena kepemimpinan itu adalah amanah dari Allah Swt kepada manusia sebagai khalifah di muka bumi. Amanah yang diberikan kepada pemimpin bukan hanya bertanggung jawab kepada rakyat, namun yang lebih besar lagi adalah tanggung jawab kepada Allah yang memberikan amanah.

Menurut Sayyid Quthub, manusia mengemban amanah yang agung yaitu amanah yang diserahkan Allah kepada fitrah manusia. Hanya manusia saja makhluk Allah yang dibarikan amanah sesuai dengan fitrahnya, akalnya, ma'rifatnya, dedikasinya dan segala usahanya yang dicurahkannya untuk mengemban misi Allah. Umat Islam yang dipasrahi amanah dan tanggung jawab kepada orang-orang yang berhak menerimanya dan menjalankan keadilan diantara manusia sesuai dengan peraturan yang dianjurkan Allah. Diantara amanah yang dipikul manusia dan pemimpin adalah membuktikan kebenaran agama Islam kepada dirinya sendiri dan kepada orang lain. Perjuangan menegakkan sistim Ilahiyyah bagi kelompok muslim dan seluruh umat manusia adalah salah satu 
amanah-amanah agung setelah tersemainya keimanan pada diri sendiri dan siapa pun itu sebagai individu maupun kelompok tidak lepas lepas dari tanggung jawab amanah ini. ${ }^{18}$

Dari pemahaman ayat diatas jelaslah bahwa Al-Qur'an (agama) memberikan mandat kepada kepala negara untuk memperjuangkan kepentingan-kepentingan dan membela kepentingan rakyat. Ibnu Taimiyah berpendapat bahwa perkataan amanah dalam ayat di atas mengandung dua makna: Pertama, amanah diartikan sebagai kepentingaan-kepentingan rakyat yang harus diperjuangkan oleh pemimpin untuk mengelolanya. Dan ini bisa berjalan dengan baik apabila mekanisme pengangkatan dan pelantikan pembatu kepala negara (Wazir/Menteri) berdasarkan kelayakan dan kepantasan seseai dengan aturan yang berlaku. Kedua, perkataan amanah diartika sebagai kewenangan dan otoritas yang dimiliki pemimpin negara Untuk melaksanakan tugasnya, dia harus memiliki pembantu-pembantu yang propesinal, sehingga dapat melaksanakan tugasnya dengan baik dan jujur. Karena pemerintahan yang tidak didasari kehlian (skil) dan kejujuran akan terjadilah pengkhianatan dan kehancuran.

Sayyid Quthub dalam menafsirkan ayat di atas, bahwa perbuatan menghindari diri dari kewajiban-kewajiban umat Islam di bumi ini merupakan suatu pengkhiatan kepada Allah dan Raslnya. Ini termasuk perbuatan tidak menarapkan hukum dan undang-undang yang disyari'atkan oleh Allah. Bahkan menurut Sayyid Qutuhub ini termasuk perbuatan syirik yaitu meyekutukan undang-undangAllah dengan undangundang lain. Perkara dalam agama Islam bukan sekedar memerintahkan manusia mempercayai Uluhiyyah, akan tetapi mengkhususkan juga kepada kuasa Hakimiyyah Allah yang menguasai kehidupan mereka dan peratutan alam dunia. ${ }^{19}$

Kemudian menurut Sayyid Quthub, bahwa Allah telah menjanjikan manusia sebagai khalifah di muka bumi kepada orang-orang yang beriman dan mengerjakan amal shalih. Allah telah berjanji untuk melantik mereka menjadi khalifah sebagaimana Allah telah melantik orang-orang yang beriman sebelum mereka supaya mereka menegakkan cara hidup dan menegakkan keadilan. Sayyid Quthub berpendapat bahwa keadilan sosial itu ada tiga dasar yaitu:Pertama:Kebebasan berkehendak secara mutlak,kedua:Persamaan manusia secara keseluruhan,ketiga:Jaminan sosial yang kuat. ${ }^{20}$ Adapun orang-orang yang berkuasa dan memerintah dengan melakukan kerusakan di 
bumi, maka mereka bukanlah khalifah yang dilantik Allah, akan tetapi mereka adalah golongan manusia yang sedang diuji Allah dengan kekuasaan yang ada pada mereka. ${ }^{21}$

Allah memberikan kekuasaan pada mereka dan Allah pula yang akan mencabutnya. Ini ditegaskan Allah dalam firmannya yang artinya: "Katakanlah: "Ya Tuban yang memiliki kerajaan, Engkau memberikan kerajaan kepada mereka yang Engkau kehendaki dan Engkau mengambil kerajaan dari mereka yang Engkau mabukan. Kamu memuliakan orang-orang yang kamu mabukan dan Engkau membenci orang-orang yang kamu inginkan. Di tangan-Mu semua kebaikan. atas semua perkara".22

Menurut ayat di atas oleh Sayyid Quthub menapsirkan, bahwa Allah lah pemilik kekuasaan yang absolut tanpa sekutu. Allah juga yang akan memberikan kekuasaan kepada siapa saja yang ia kehendaki, sebagai amanah yang harus dipertanggung jawabkan. Sebagaimana sabda Rasulullah saw yang artinya : "Setiap dari kamu adalah pemimpin, dan akan dimintak pertanggung jawabannya atas orang yang di pimpinnya"." 23

Tiada seorang pun yang mempunyai hak milik yang mutlak, untuk berbuat dengan sesuka hatinya karena hak milik itu adalah pinjaman yang harus tunduk kepada syarat-syarat dan perintah pemilik sejati. Apabila manusia bertindak sewena-wena maka tindakannya adalah tidak sah dan wajib mengembalikan kekuasaan itu di dunia dan di akhirat kelak akan dihisab terhadap tindakannya yang salah dan bertentangan dengan pemilik-Nya. ${ }^{24}$

Dalam pemerintahan Allah, terdapat kebajikan dan kebaikan belaka. Dia menjalankan pemerintahan dengan adil dan seksama. Allah berbuat sekehendaknya. Allah memberikan kekuasaan kepada siapa yang dikehendaki-Nya dan mencabutnya secara adil dan bijaksana. Dia memuliakan dan menghinakan siapa pun yang dikehendaki-Nya dengan adil dan seksama. Keadilan itu adalah kebaikan yang hakiki yang sesuai dengan Iradah dan Qurat-Nya yang mutlak untuk merealisasikan kebaikan dan kebajikan dalam segala hal. ${ }^{25}$

Allah adalah pemilik kedaulatan mutlak. Kedaulatan atau supremasi kekuasaan adalah bersandarkan kepada konsep kedaulatan Allah. Al-Qur'an sebagai sumber naqli secara tegas menyatakan bahwa kedaulatan dalam semua aspek hanya berada di tangan Allah. Hanya Dialah Pencipta da Penguasa sebenarnya dialam semesta. Oleh karenanya, 
semua kekuasaan ada di Tangannya dan yang mempunyai hak kedaulatan mutlak atas semua makhluk-Nya.

Doktrin tentang kekuasaan dan kedaulatan Allah, yang melampaui batas kedaulatan manusia tertuang dalam ayat berikut, yang artinya: "Anda tidak menyembah apaapa selain Allah kecuali hanya (menyembah) Nama-nama yang anda dan nenek moyang anda buat. Allah tidak menyatakan maklumat mengenai Nama-nama tersebut. keputusan itu hanya milik Allah. Dia telah memerintabkan agar kamu tidak menyembah selain Dia. Ini adalah agama yang benar, tetapi kebanyakan orang tidak tahu. ${ }^{126}$

Menurut Sayyid Quthub dalam tafsirnya tentang ayat di atas, kedaulatan dan pemerintahan itu adalah mutlak milik Allah, berdasarkan sifat Uluhiyah-Nya. Barang siapa yang mengklaim memiliki kekuasaan seperti itu berarti ia telah mendeklarasikan diri menjadi kapir terhadap Allah. Kekuasaan yang diberikan oleh rakyat ada batasnya dan harus bersandarkan kepada syari'at yang telah ditentukan Allah walaupun sang penguasa mendapat legitimasi dari rakyat. Rakyat bukan sumber utama Hakimiyah yang memberikan legalitas dalam menciptakan undang-undang. Seluruh manusia tidak memiliki kuasa Hakimiyah karena hanya saja Allah saja yang memilikinya. Tugas manusia hanya menjalankan pemerintahan dan melaksanakan undang-undang yang disyari'atkan Allah. Setiap undang-undang yang tidak berpijak kepada syari'at Allah, maka undang-undang itu tidak mempunyai asas legalitas yang sah menurut Allah. ${ }^{27} \mathrm{Al}$ Qur'an berulang kali menyatakan tentang masalah hak kedaulatan dan kekuasaan yang dimilikinya:

Artinya: "Sesunggubnya Tuhanmu adalah Pelaksana apa yang Dia kehendaki".

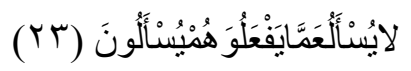

Artinya: "Dia tidak ditanya apa yang Dia lakukan dan mereka akan ditanya"."

\section{Sistem Pemerintahan Islam}

Sayyid Quthb berpendapat bahwa sistem pemerintahan dalam Islam merupakan satu asas yang lengkap dan sempurna. Sistem Islam merupakan sistem yang khas, 
sehingga Sayyid Quthb tidak sependapat dengan pemikiran-pemikiran yang mencari kemiripan antara sistem Islam dengan sistem-sistem lain. Sistem Islam tidak memerlukan dukungan dan kemiripan dan kesamaannya dengan sistem lain, karena hal itu merupakan perasaan rendah diri yang tidak akan mungkin dikemukakan oleh seorang penulis Islam sepanjang ia memahami hakekat ajaran Islam dan melakukan pembahasan dengan sejujur-jujurnya. ${ }^{30}$

Bahkan Sayyid qutb mempunyai konsep mengenai pemerintahan yang ideal dalam Islam. Menurutnya, kerajaan terbaik adalah kerajaan Supra Nasional. Dalam sistem ini, wilayah Negara meliputi seluruh dunia Islam dengan pemusatan kuasa dalam pemerintahan pusat. Yang dikendalikan berdasarkan prinsip persamaan penuh antara semua umat Islam di seluruh dunia Islam, tanpa fanatik perkauman dan wilayah. Mengenai pemanfaatan potensi pendapatan yang dimiliki oleh wilayah tersebut, diutamakan untuk digunakan untuk kepentingan wilayah itu sendiri, dan jika masih ada lagi, dana tersebut akan dimasukkan ke Bait al-Mal atau perbendaharaan pemerintah pusat sebagai harta bersama umat Islam yang akan digunakan untuk kepentingan bersama apabila diperlukan. ${ }^{31}$

Al-Qur'an juga menguraikan dengan jelas mengenai mengapa kaum muslim harus berusaha secara sungguh-sungguh untuk menciptakan dan menegakkan negara mereka sendiri yang tentunya harus berdimensikan islam. Pembentukan negara yang bersendikan Islam ini dinyatakan dalam Al-Qur'an yang artinya: "Allah telab berjanji kepada orang-orang yang beriman di antara kamu dan melakukan perbuatan baik bahawa Dia akan menjadikan mereka memerintah di bumi, sebagaimana Dia menjadikan orang-orang sebelum mereka memerintah, dan sesunggubnya Dia akan menegaskan bagi mereka agama mereka. apa yang Dia mabukan untuk mereka, dan Dia akan mengubahnya sepenubnya, setelah mereka takut selamat. mereka masih menyembah saya dengan tidak memberikan apa-apa kepada saya dan barang siapa (tetap) tidak percaya setelah (janji), maka mereka adalah orang-orang yang fasik.".

Sayyid Quthub dalam tafsirnya Fi Zilalil Qur'an, memberikan uraian yang cukup panjang mengenai ayat di atas sebagai justifikasi kewajiban menegakkan negara yang berdimensikan Islam. Menurut Qutb, pelantikan manusia sebagai khalifah Allah di atas bumi ini bukannya semata-mata kekuasaan, menaklukkan wilayah asing dan memerintah. Malah fungsi khalifah adalah merangkumi semuanya dengan tujuan untuk digunakan 
untuk mencapai kemaslahatan, pembangunan, pembinaan, dan seterusnya menegakkan sistem hidup yang telah digariskan Allah swt untuk umat manusia. ${ }^{33}$

Meskipun demikian Sayyid Quthb menolak dengan keras bila dikatakan Islam menganut sistem imperium yang dipahami dari sejarah Islam klasik. Menurut Sayyid Quthb Islam memiliki pandangan bahwa semua umat Islam yang terdapat di seluruh penjuruh dunia Islam adalah setara, dan menolak adanya fanatisme ras dan kedaerahan, dan bahkan fanatisme keagamaan; dan sesuai dengan semangatnya ini, maka Islam tidak menjadikan wilayahnya yang terdapat di mana-mana itu sebagai daerah jajahan atau negeri taklukan, dan tidak pula diekploitasi demi kepentingan pusat sendiri. Setiap wilayah Islam merupakan bagian dari keseluruhan dunia Islam dan semua warganya memiliki hak-hak yang sama dengan warganegara yang berada di pusat pemerintahan Islam. Dan bila sebagian wilayah-wilayah itu ada yang diperintah oleh seorang Gubernur (wali) yang diangkat oleh pusat, maka posisinya sebagai gubernur itu, semata-mata hanyalah sebagai seorang muslim yang memang pantas menduduki jabatan itu, dan bukan sebagai seorang penjajah yang berkuasa, maka wilayah-wilayah itu selalu terbuka untuk diperintah oleh putra-putra daerahnya masing-masing. ${ }^{34}$ Oleh karena itu sistem pemerintahan Islam bercorak manusiawi, terutama konsepsinya yang kuat tentang kesatuan manusia serta tujuannya yang menghendaki seluruh umat manusia terhimpun di bawah bendera persaudaraan yang sama dan sederajat. ${ }^{35}$

Pandangan Sayyid Quthb di atas mencerminkan bahwa Islam tidak anti terhadap nilai-nilai yang diperjuangkan dalam sistem demokrasi. ${ }^{36}$ Kajian demokrasi dalam Islam tidak didasari oleh pandangan demokrasi sebagai produk pemikiran barat semata namun, kajian demokrasi dilandasi oleh semangat mencari nilai-nilai untuk mewujudkan sistem pemerintahan yang baik dan bersih.

Nilai-nilai demokrasi yang diperjuangkan oleh masyarakat dewasa ini, memiliki beberapa kesamaan konsep dengan dasar pemerintahan Islam yang telah ditawarkan oleh Sayyid Quthb, yaitu; permusyawaratan antara penguasa dengan rakyat. Menurut Sayyid Quthb permusyawaratan merupakan salah satu prinsip di antara prinsip-prinsip pemerintahan Islam; sedangkan tehnisnya secara khusus tidak ditetapkan. ${ }^{37}$ Dengan demikian bentuk musyawarah terserah pada kepentingan dan kebutuhan sesuai kondisi pemerintah dan masyarakat. Meskipun musyawarah merupakan sistem dan lembaga 
tertinggi yang telah ditetapkan oleh Islam, dan perkembangan zaman selalu membutuhkan musyawarah, namun musyawarah tidak sekedar mendengarkan suara rakyat. Hal itu karena, pada umumnya kehidupan masyarakat terbuka bagi berbagai bentuk sistem yang bathil yang tidak ditetapkan oleh Islam.

Menurut al-Maududi yang dikutip oleh Musdah Mulia, menyebutkan ada enam prinsip dasar negara Islam, yaitu kekuasaan perundang-undangan berada di tangan Allah, negara Islam pada hakekatnya adalah khalifah atau perwakilan, keadilan antar manusia, persamaan antarmanusia, negara dipegang oleh orang-orang bertakwa, adil, dan beriman, musyawarah dan kewajiban mematuhi pemimpin selama ia patuh kepada Allah. Sementara menurut Sa'di Abu Hhabib prinsip negara Islam harus terdiri, yaitu kekuasaan perundangan ada di tangan Allah, persatuan, persamaan, musyawarah, kebebasan, dan keadilan. ${ }^{38}$

Prinsip-prinsip pemerintahan sebagaimana yang disuarakan oleh pemikir-pemikir Islam di atas, nampak memiliki nuasa yang khas, meskipun demikian tidak bertentangan dengan prinsip demokrasi. Prinsip pemerintahan dalam pemikiran Islam menjadi bahan kritis untuk sistem pemerintahan dalam pemikiran politik sekuler dewasa ini. Pemerintahan baik sekular yang mengabaikan sumber nilai agama dibina dari keadaan yang ada dalam masyarakat yang bersangkutan, sesuai dengan peraturan, norma, tabiat atau budaya dalam masyarakat dalam masyarakat tertentu. Nilai-nilai yang ada dan berkembang dalam masyarakat mewarnai sikap dan tingkah laku yang kemudiannya dilihat beretika atau tidak beretika dalam pelaksanaan fungsi pemerintahan yang merupakan sebahagian dari fungsi alat birokrasi itu send. ${ }^{39}$

\section{Pilar-Pilar Pemerintahan Islam}

Bagi Sayyid Quthub, politik Islam dibentuk diatas tiga pilar utama yaitu; pertama, keadilan penguasa.Kedua, ketaatan rakyat.Ketiga, permusyawaratan antara rakyat dengan penguasa.Ketiga pilar tersebut merupakan bagian pokok dalam konsep politik Islam. Ketiganya tidak bisaberdirisendir inamun saling mendukung antara satu dengan yang lain. $^{40}$ 
1) Keadilan penguasa di sini lebih memfokuskan kepada orang yang memerintah yang mesti benar-benar adil dalam dasar dan keputusan tanpa diskriminasi.

2) Ketaatan rakyat kepada penguasa adalah perpanjangan ketaatan kepada Allah dan para rasulnya. Namun, ketaatan di sini bukan kerana kedudukan tetapi kerana mereka menegakkan syariat Allah dan Rasul-Nya. Batasan kepatuhan kepada ulil 'amri bukan di institusi tetapi sama ada penguasa menjalankan undang-undang Islam atau tidak.41 Melaksanakan undang-undang Islam adalah tawaran mutlak yang mesti ada pada penguasa walaupun sistem pemerintahan dijalankan secara berbeza. Logiknya bertentangan (mafhum mukhalafah) dari ini dibenarkan untuk tidak mematuhi pemerintah yang zalim, tidak mematuhi undang-undang Islam dan sebagainya. Dalam prinsip politik ini, nampaknya pendapat ini memerlukan sokongan. Sekiranya diambil dari konteks Indonesia, ada kebutuhan untuk reformasi moral dan spiritual bagi para pemimpin Negara agar mereka dapat bertindak dengan adil dan tidak korup. Dengan cara ini, konsep kepatuhan kepada pihak berwajib dalam konteks ini dapat dilaksanakan. Adapun berurusan dengan penguasa yang zalim, asalkan dapat diperbaiki melalui kelembutan dan politik yang baik, mengapa harus dilakukan secara paksa. Kecuali jalan-jalan lain ditutup, Indonesia juga membuktikan bahawa rampasan kuasa dapat dilakukan selagi kezaliman penguasa tidak dapat ditoleransi, walaupun pada kenyataannya rampasan kuasa tidak menyelesaikan masalah selagi reformasi moral dan rohani tidak dilakukan .

3) Tentang permusyawaratan antara rakyat dan penguasa adalah salah satusistem Islam yang harus dijalankan sebagai asas pemerintahan yang sudahdipraktekan sejak masa Nabi. Dalam hal ini menurut penulis, untuk konsep negarabangsa, dapat dipastikan bahwa hanya negara yang memiliki demokrasi yangmapanlah yang dapat melakukan permusyawaratan yang baik. Karenapermusyawaratan ini adalah bentuk transparansi penguasa kepada rakyat dalammenentukan arah dan kebijakannya. Sedangkan sebuah negara yang berorientasikan pemerintah, musyawarah hanya merupakan kegiatan sia-sia kerana kepentingan yang diinginkan bukanlah kemakmuran rakyat, tetapi kemakmuran pemerintah dan kroninya. 


\section{Konsep Pemikiran Taqiyyuddin Al-Nabhani}

\section{Tentang Khalifah (Penguasa)}

Khalifah adalah orang yang mewakili ummah dalam urusan pemerintahan dan kekuasaan dan dalam melaksanakan undang-undang syara'. ${ }^{42}$ Islam telah menjadikan pemerintahan dan kekuasaan menjadi milik ummah, ummah mewakili seseorang untuk menjalankan urusan ini - sebagai wakil mereka. Bahkan Allah juga mewajibkan umat untuk melaksanakan hukum syara 'secara keseluruhan.

Oleh itu, khalifah hanya orang yang dilantik oleh orang Islam. Oleh itu, hakikatnya adalah bahawa khalifah adalah wakil ummah dalam hal pemerintahan dan kekuasaan serta dalam melaksanakan hukum syara '. Oleh itu, tidak ada seorang khalifah kecuali setelah dia disumpah oleh rakyat. Ikrar umat kepada khalifah dengan khilafah telah menjadikan khalifah sebagai wakilnya, dan pelantikan khalifah kepada khalifah dengan bai'at bererti bahawa dia telah memberikan kekuasaan kepada khalifah, sehingga orang-orang wajib taat dia.

Orang yang memimpin urusan umat Islam tidak boleh disebut khalifah, kecuali setelah dia diabadikan oleh orang-orang dengan bai'at in'iqad (janji bai'at) dalam syar "i, dengan persetujuan dan pilihan bebas, khalifah mempunyai syarat-syarat ini iqadul khilafah (janji untuk menduduki khilafah) Setelah pelantikan khalifah dinyatakan sah untuk khalifah, dia harus segera menerapkan hukum syara 'dengan serius. ${ }^{43}$

Sementara istilah yang biasa digunakan adalah istilah khalifah, imam atau amirul mukmin. Tajuk-tajuk ini banyak dinyatakan dalam hadis sahih. Oleh kerana sebutan ini telah diberikan kepada khulafaur rasyidin. Abu Said Al Khudri meriwayatkan dari Nabi Muhammad. bahawa dia berkata:

$$
\text { اذا بويع اخليفتين فاقتلوا الاخر منهما }
$$

Artinya: "Sekiranya dua khalifah setia, maka bunublah yang kedua".

Dari Abdullah Bin Amru Bin Ash yang mendengarkan Rasullah saw. bersabda:

$$
\text { ومن بانع اماما فاعطاه صفقة يده وثمرة قلبه فلبطعه }
$$


Artinya: "Siapakah saya yang telah berjanji kepada seorang Imam dan kemudian memberikan tangan pertolongan dan bayinya, lalu biarkan dia mematubinya". 45

Tidak terikat dengan ketiga-tiga sebutan di atas. Bahkan dibenarkan memanggil orang yang memimpin urusan orang Islam dengan nama lain yang mempunyai maksud yang sama. Seperti Hakimul mukminin (penguasa orang-orang yang beriman), raisul Muslimin (pemimpin umat Islam), Sulthanul Muslimin (penguasa umat Islam) atau istilah lain yang dilihat dari segi makna tidak bertentangan dengan tiga istilah di atas. Mengenai tajuk yang mempunyai konotasi yang bertentangan dengan undang-undang Islam yang berkaitan dengan urusan pemerintahan, seperti raja, presiden dan maharaja, semuanya tidak dapat digunakan untuk merujuk kepada orang yang memimpin umat Islam. Kerana makna yang ditunjukkan oleh sebutan itu bertentangan dengan undangundang Islam. ${ }^{46}$

\section{Syarat-syarat Khalifah}

Seorang khalifah harus memenuhi tujuh syarat agar dia dapat memegang tampuk pemerintahan khilafah, juga agar kesetiaan terhadap pelantikan jawatan khilafahnya dapat diberikan. ${ }^{47}$ Ketujuh syarat ini adalah syarat undang-undang untuk pelantikan khalifah (syurutul in'igad). Sekiranya salah satu daripada tujuh syarat itu kurang, jawatan khalifah ini tidak dapat diberikan.

Pertama, umat Islam. Oleh itu, Khilafah sama sekali tidak boleh diberikan kepada orang kafir. Dan hukumnya tidak wajib untuk mematuhi orang kafir. Kerana Allah swt. Berkata yang bermaksud: "Dan Allah tidak akan pernab memberi jalan bagi orangorang kafir untuk membinasakan orang-orang yang beriman. ${ }^{48}$

Pemerintahan (kekuasaan) adalah cara paling ampuh bagi hakim (penguasa) untuk memaksa rakyatnya. Ditambah dengan pernyataan Allah dengan menggunakan "Lan" yang biasanya digunakan untuk menyatakan penafian abadi (nafyut ta'bid) itu dapat menjadi petunjuk (qarinah) larangan terhadap orang kafir untuk memimpin pemerintahan umat Islam, keduanya menjadi khalifah dan kepada orang lain. semua ini adalah larangan yang ketat dan pasti (nahyan jaziman). Selagi Allah melarang orang kafir 
mempunyai jalan untuk mengawal umat Islam, hukumnya haram bagi orang Islam untuk menjadikan orang kafir sebagai pemerintah mereka. ${ }^{49}$

Di samping itu, khalifah pada hakikatnya adalah waliyul amri, sementara Allah menghendaki agar waliyul amri orang Islam menjadi Muslim. Allah berfirman Q.S. An Nisa ': 59, yang bermaksud: "Hai orang-orang yang beriman, taatlah kepada Allah dan taatilah Rasul-Nya, dan ulil amri dari kamu semua. ${ }^{150}$

Kata ulil amri tidak pernah disebut dalam Al Ciur'an, kecuali selalu disertakan dengan petunjuk bahawa mereka adalah orang Islam. Ini menunjukkan bahawa waliyul amri diharuskan menjadi seorang Muslim. Sekiranya khalifah adalah waliyul amri, dia juga dapat melantik waliyul amri yang lain, seperti mu'awins, wali dan amil, orang yang dilantik oleh khalifah wajib menjadi seorang Muslim.

Kedua, lelaki. wanita tidak boleh menjadi khalifah. Dengan kata lain, khalifah mestilah lelaki. Dia tidak boleh menjadi wanita. Berdasarkan hadis yang diriwayatkan oleh Abi Bakrah yang mengatakan: "Sesungguhnya Allah swt. Telah memberi manfaat kepada saya - dari kata-kata yang pernah saya dengar dari Rasulullah saw. Semasa perang Jamal, setelah awalnya saya hampir mengikuti tentera Jamal (dipimpin oleh Ayesha yang unta) dan berjuang di pihak mereka ". Kemudian dia melanjutkan: "Ketika berita sampai kepada Rasulullab bahawa orang-orang Parsi telah mengadopsi puteri Kisra sebagai ratu, dia berkata:" Tidak akan beruntung bagi seseorang untuk. menyerabkan kekuasaan (pemerintahan) mereka kepada seorang wanita. ${ }^{151}$

Ikblas (pemberitahuan) Nabi dengan menafikan keberuntungan kepada mereka yang menyerabkan kekuasaan mereka kepada seorang wanita adalah larangan terhadap kepemimpinan wanita. Kerana pernyataannya adalab shiyagut thalab (bentuk pesanan). Plus pemberitabuan itu adalah pemberitabuan yang berisi celaan (adz-dzam) kepada mereka yang menyerabkan kekuasaan mereka kepada seorang wanita, dengan menyangkal keberuntungan mereka, itu dapat digunakan sebagai petunjuk (qarinah) bahawa celaan itu adalah larangan yang pasti dan ketat. Sehingga larangan untuk melantik seorang wanita ke posisi berkuasa disertai dengan petunjuk yang menunjukkan permintaan untuk meninggalkan perbuatan itu dengan pasti. Jadi, melantik wanita sebagai pemerintah adalah haram. Yang dimaksudkan dengan larangan melantik seorang wanita untuke. menjadi penguasa di sini adalah dengan menduduki posisi kekhalifahan dan posisi kekuasaan di bawabnya. Kerana apa yang dibincangkan di sini adalah pengangkatan Puteri Kisra sebagai ratu yang berkuasa. Jadi masalahnya secara khusus adalah masalah pemerintahan, bukan secara khusus 
mengenai kejadian pelantikan Puteri Kisra sahaja, tetapi itu tidak bermaksud bahawa jeneral merangkumi segalanya. Oleh itu, larangan ini tidak merangkumi perkara-perkara selain pemerintaban.

Ketiga, baligh. Anak-anak tidak boleh dilantik menjadi khalifah. Kerana ada riwayat dari Ali Bin Abi Talib ra. bahawa Rasulullah saw. kata:

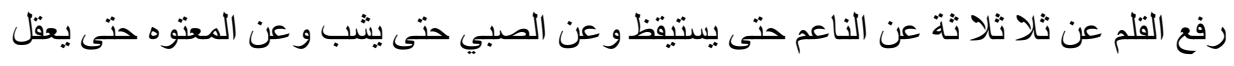

Artinya: " Pena (tidak ada undang-undang yang dikenakan) pada orang yang tidur sehingga dia bangun, agar anak kecil mencapai usia matang, dan orang gila sehingga fikirannya kembali. ${ }^{152}$

Sesiapa yang telah mengambil pena daripadanya tidak sah untuk menguruskan kesnya. Kerana menurut syara ', dia tidak dibebani oleh hukum (ghairu mukallaf). Jadi, dia tidak sah menjadi khalifah, atau menjadi pejabat yang memiliki kekuasaan, kerana dia tidak dapat mengatur kekuasaan. Hujah lain adalah bahawa Rasulullah saw. tidak pernah menolak anak yang mahu membawanya.

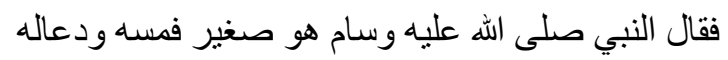

Artinya: Rasulullah saw. menolak bai pada Abdullah Bin Hisham dan dia memberi alasan kerana dia masib kecil. Nabi berkata kepada ibunya: "Dia masih kecil." 53

Kemudian dia mengusap kepalanya dan mendoakannya. Sekiranya bai'at tidak dapat diberikan oleh anak kecil dan anak itu tidak dapat mengambil kesetiaan orang lain sebagai khalifah, tidak boleh lagi baginya menjadi khalifah.

Keempat, bijaksana. Tidak sah bagi orang gila untuk menjadi khalifah berdasarkan sabda Nabi saw: Maksudnya: "Pena (tidak ada bukum yang dikenakan) pada orang yang tidur sehingga dia bangun, seorang anak. kecil mencapai usia matang, dan orang gila telah kembali sedar. "

Barangsiapa pena diangkat darinya, dia bukan seorang mualaf. Kerana akal menjadi manath (tempat) pengenaan hukum dan syarat hukum untuk mengatur berbagai urusan. Sementara itu, tugas khalifah adalah menguruskan urusan 
Memerintah dan melaksanakan perintah syara ', tidak sah jika Khalifah adalah orang gila. Kerana orang gila tidak dapat mengurus perniagaannya sendiri, apalagi mengurus perniagaan orang lain. Oleh itu, adalah lebih tidak sah bagi orang gila untuk mengurus urusan orang lain dengan menjadi khalifah. ${ }^{54}$

Kelima, adil, iaitu orang yang konsisten dalam menjalankan agamanya (takut dan menjaga mum'ah). Jadi tidak sah bagi orang jahat untuk diangkat menjadi khalifah. Adil adalah syarat yang mesti dipenubi untuk pelantikan khalifah dan kesinambungan kontrak pelantikan.55 Kerana, Allah SWT. telah memerlukan saksi dengan syarat 'adalah (adil). Allab berfirman: "Kamu seharusnya menjadi saksi dua lelaki adil dari kamu semua. ${ }^{56}$

Sudah tentu, kedudukan khalifah lebih tinggi daripada saksi. Oleh itu, sudah tentu dia mempunyai situasi yang adil yang lebih penting. Kerana jika saksi hanya menetapkan syarat yang adil, terutama jika syarat itu untuk khalifah.

Keenam, kemerdekaan. Seorang hamba tidak sah menjadi khalifah, kerana dia adalah milik tuannya sehingga dia tidak memiliki wewenang untuk memerintah, bahkan atas dirinya sendiri. Dengan demikian, dia tidak layak menjaga orang lain, apalagi menjadi penguasa manusia. ${ }^{57}$

Ketujuh, dapat menjalankan amanah khalifah. Kerana ini adalah salah satu syarat yang dituntut oleh bai'at. Jadi, adalah tidak sah untuk memberikan taat setia kepada seseorang yang tidak mampu menjalankan urusan umat (amanat khalifah) berdasarkan kitab dan sunnah. Kerana berdasarkan kitab dan sunnab itulah dia diambil alih. ${ }^{58}$

\section{Tentang system Pemerintahan}

Menurut Taqiyuddin Al-Nabhani bahwa sistem pemerintahan Islam adalah khilafah. ${ }^{59}$ Menurut Al-Nabhani, dalam sistem pemerintahan Islam tidak ada menteri atau kementerian dengan kepala negara seperti dalam konsep demokrasi, yang memiliki pengkhususan dan jabatan tertentu. Dia menjelaskan bahawa dalam sistem pemerintahan Islam hanya ada mu'awin (pembantu ketua negara) yang selalu diminta pertolongan oleh ketua negara. Tugas mereka adalah untuk membantu ketua negara dalam tugas-tugas pemerintah. Mereka berdua adalah pembantu dan pelaksana. Ketika ketua negara memimpin mereka, ketua negara memimpin mereka bukan dalam kapasitas mereka sebagai perdana menteri atau ketua cabang eksekutif, tetapi hanya sebagai 
penguasa negara. Kerana dalam Islam tidak ada menteri kabinet yang ditugaskan untuk membantu khalifah dengan memiliki kekuatan tertentu. Oleh itu, mu'awin masih hanya pembantu khalifah untuk menjalankan kuasanya. ${ }^{60}$

Menurut Taqiyuddin Al-Nabhani, negara khilafah bukanlah negara teokrasi. Sebab, khilafah merupakan jabatan yang memiliki semua wewenang pemerintahan dan kekuasaan, serta wewenang membuat peraturan tanpa terkecuali. Menurut Taqiyuddin Al-Nabhani, khilafah merupakan jabatan duniawi dan bukan jabatan ukhrawi. Peranan khalifah adalah menerapkan agama Islam kepada seluruh umat manusia. Khilafah bukan merupakan (nubuwat) jabatan kenabian, sebab jabatan kenabian merupakan jabatan di mana para nabi memperoleh syariat dari Allah melalui wahyu agar disampaikan kepada manusia, dengan tanpa memandang syariat tersebut diterapkan. Menurut Taqiyuddin AlNabhani, hal ini tentu berbeda dengan khilafah. Sebab, khilafah justru untuk menerapkan syariat Allah kepada seluruh manusia. ${ }^{61}$

Identik dengan pandangan tersebut, Yusuf Qardhawi menyatakan bahwa Daulah Islam bukan teokrasi. Daulah teokrasi hanya dikenal di Barat dalam sejarahnya. Ketika itu, daulah di tangani para pemimpin gereja yang menganggap segaia perilaku mereka terjaga dari kesalahan dan suci. Sikap gerejawan ini mendapat pertentangan, yang berakhir dengan pecahnya revolusi terhadap dominasi gereja. Menurut Yusuf Qardhawi, salah besar jika daulah Islam disebut daulah teokrasi. Alasannya, Daulah Islam adalah daulah sipil yang ditegakkan atas pemilihan, bai'at dan syura. Tanggung jawab pemimpin ada di hadapan umat, dan hak setiap rakyat adalah mengingatkan pemimpinnya. Pemimpin dalam daulah Islam terikat dengan syariat yang memberikan ketentuan hukum kepadanya. ${ }^{62}$

Dalam pandangan Al-Nabhani, realita ini berbeda dengan sistem kekhalifahan. Dalam sistem khilafah, seorang Amirul Mukminin (Khailfah), meskipun bertanggungjawab dihadapan umat dan wakil-wakilnya, umat termasuk wakilnya tidak berhak untuk memberhentikannya. Khalifah juga tidak akan diberhentikan kecuali apabila menyimpang dari hukum syara' dengan penyimpangan yang menyebabkanya harus diberhentikan. Adapun yang menentukan pemberhentiannya adalah hanya mahkamah mazhalim. ${ }^{63}$ 
Dalam perspektif Al-Nabhani, kedudukan pemerintah (presiden atau perdana menteri) dalam sistem republik, baik presiden maupun parlimen, selalu terbatas pada jangka waktu tertentu, yang mungkin tidak melebihi jangka masa itu. Sementara itu, dalam sistem Khilafah, tidak ada jangka waktu tertentu. Namun, satu-satunya had adalah sama ada mereka masih menerapkan hukum syara 'atau tidak. Oleh itu, selagi Khalifah masih menjalankan hukum syara ', dengan menerapkan hukum-hukum ini kepada semua manusia dalam pemerintahannya, yang diambil dari Kitab Allah dan sunnah rasul-Nya, dia tetap menjadi khalifah, walaupun jangka masa sangat panjang dan panjang. Kemudian ketika dia telah meninggalkan undang-undang syara 'dan menghentikan penerapan undang-undang tersebut, masa jabatannya akan berakhir, walaupun masa jabatannya hanya satu hari dan malam. Oleh itu masih wajib diberhentikan. ${ }^{64}$

Dari penjelasan tersebut, Taqiyuddin Al-Nabhani menyimpulan uraiannya bahwa sistem pemerintahan di dalam Islam adalah sistem khilafah. ${ }^{65}$ Taqiyuddin AlNabhaniberalasan bahwa Ijma' Sahabat telah sepakat terhadap kesatuan khilafah, kesatuan negara serta ketidak-bolehan berbai'at selain kepada satu Khalifah. ${ }^{66}$

\section{Pilar-PilarPemerintahan Islam}

Dalam pandangan Taqiyuddin Al-Nabhani bahwa sistem pemerintahan Islam tidak bisa dicari padanannya di bandingkan dengan sistem pemerintahan di luar Islam. Untuk mendukung pemikirannya tentang sistem pemerintahan Islam, terutama letak perbedaan yang mendasar sistem pemerintahan Islam dengan sistem pemerintahan modern, tokoh politik Islam ini, telah merumuskan bahwa sistem pemerintahan Islam dapat tegak di atas ernpat pilar: 1). Kedaulatan di tangan syara', 2). Kekuasaan milik umat, 3). Mengangkat satu Khalifah hukumnya fardlu bagi seluruh kaum muslimin, dan 4). Hanya Khailfah yang berhak melakukan tabanni (adopsi) terhadap hukum-hukum syara'. Khalifah yang berhak membuat undang-undang dasar dan semua undang-undang yang lain. ${ }^{67}$

\section{Kedaulatan di tangan syara'.}

Dalam sistem pemerintahan demokrasi, rakyat adalah pemegang kedaulatan. Artinya, rakyatlah yang memiliki suatu kemauan atau kehendak. ${ }^{68}$ Karena itu, kedaulatan 
rakyat bermakna kehendak ada di tangan rakyat. Aktualisasi dari kebebasan berkehendak tersebut adalah wewenang untuk membuat hukum dalam rangka merealisasikan kehendaknya.

Karenanya, kedaulatan rakyat, segala perkara terserah rakyat, boleh atau tidak terserah rakyat, halal-haram tergantung pada rakyat; sesuatu boleh atau tidak berkembang di tengah masyarakat terserah rakyat. Aturan yang akan diberlakukan terserah rakyat.Rakyat dapat mengubah sistem ekonomi, politik, budaya, sosial, dan apa pun sesuai dengan kehendaknya. Rakyatlah yang berhak membuat Undang-undang dan Undang-undang Dasar sebagai wujud keinginannya. Rosseau menilai bahwa keinginan umum tersebut harus berlaku sebagai suatu wewenang memaksa, tertinggi, karena ia menyamai kebaikan umum. ${ }^{69}$ Konsekuensi logisnya, dalam negara demokrasi, rakyat dijadikan 'Tuhan'. Karenanya, para penganutnya meyakini suara rakyat adalah suara Tuhan (Vox Populi, Vox Dei).

Menurut Taqiyuddin Al-Nabhani bahwa kedaulatan tersebut adalah di tangan syara' dan bukan di tangan umat. ${ }^{70}$ Dia berpendapat bahawa kata as-siyadah, yang bermaksud kedaulatan sebenarnya adalah istilah Barat. Sementara itu, yang dimaksud dengan kata as-siyadah adalah mereka yang menangani (mumaris) dan melaksanakan (musayyii) kehendak atau aspirasi! (iradah) tertentu.

Pada pandangan Taqiyuddin Al-Nabhani bahawa jika ada seseorang yang menangani dan mengawal aspirasinya, sebenarnya kedaulatan itu berada di tangannya sendiri. Apabila cita-cita orang itu berada di tangan dan dikendalikan oleh orang lain, orang itu pada dasarnya telah menjadi abdun (hamba) bagi orang lain. Sekiranya aspirasi ummah atau sekelompok orang ditangani dan dikendalikan oleh orang itu sendiri, dengan perantaraan individu mereka, maka ummah akan memberi mereka hak untuk mengendalikan dan mengendalikannya secara sukarela, mereka (individu ummah) adalah sayyid (tuan) untuk ummah. Sekiranya aspirasi rakyat ditangani dan dikawal oleh orang lain secara paksa, maka rakyat telah menjadi hamba mereka (jajahan).

Mengamati kenyataan ini, menurut Taqiyuddin Al-Nabhani, bahawa sistem demokrasi dengan kedaulatan di tangan rakyat itu sendiri bermaksud bahawa rakyat menangani dan mengawal aspirasi mereka. Rakyat akan melantik siapa sahaja yang mereka mahukan dan akan memberikan hak untuk menangani dan mengawal aspirasi 
mereka kepada siapa sahaja yang mereka mahukan. Inilah hakikat kedaulatan, yang menurut Al-Nabhani benar-benar menghilangkan kekuasaan di bahu rakyat. ${ }^{71}$

Taqiyuddin Al-Nabhani berpendapat bahawa apa yang benar ialah kedaulatan berada di tangan syara ', bukan di tangan rakyat. Dia berpendapat bahawa orang yang menangani dan mengendalikan aspirasi individu adalah syara ', bukan individu itu sendiri yang dikehendaki, tetapi aspirasi individu ditangani dan dikendalikan berdasarkan perintah dan larangan Allah. Argumen yang berkaitan dengan kedaulatan ini adalah firman Allah (QS. An-Nisa ': 65), yang bermaksud: "Oleb itu oleb Tuhanmu, mereka (pada bakikatnya) tidak beriman sehingga mereka menjadikanmu hakim dalam suatu perkara yang mereka mempertikaikan hati mereka terbadap keputusan yang anda berikan, dan mereka menerimanya sepenubnya". ${ }^{72}$

Allah menjelaskan bahawa mereka yang memerintah di antara orang-orang dan individu dan yang menangani dan mengawal aspirasi adalah apa yang dibawa oleh Rasulullah. Umat Islam mesti tunduk dan patuh kepadanya, kata Allah QS. An-Nisa ': 59, yang bermaksud: "Hai orang-orang yang beriman, taatlah kepada Allah dan taatilah RasulNya, dan Pemimpin di antara kamu. Kemudian jikea anda mempunyai pendapat yang berbeza tentang sesuatu, maka kembalikan kepada Allab (Al-Kitab) dan Rasul (Sunnab), jïka anda benar-benar percaya kepada Allah dan ya kemudian". ${ }^{73}$

Allah tidak pernah memerintahkan taat kepada orang yang tidak ada. Hal inimenunjukkan bahwa mewujudkannya adalah wajib. Sehingga ketika Allah memerintahkan taat pada ulil amri, merupakan perintah untuk mewujudkannya. Adanya ulil amri memiliki konsekuensi tegaknya hukum Islam, tidak mewujudkan membawa konsekuensi tidak tegaknya hukum Islam, hukum mewujudkan ulil amri adalah wajib.

Pengertian "Kembalikan ia kepada Allab dan Rasul" adalah "Kembalikan kepada bukum syara". Dari hujah-hujah ini, Taqiyuddin Al-Nabhani berpendapat bahawa mereka yang memerintah di tengah-tengah ummah dan individu dan yang menangani dan mengawal aspirasi umat dan individu adalah apa yang dibawa oleh Rasulullah, umat dan individu mesti tunduk kepada syara'. ${ }^{74}$

Dalam perspektif Taqiyuddin Al-Nabhani bahwa seorang Khalifah tidak akan dibai'at oleh umat sebagai ajir (pekerja, buruh, atau pegawai) umat agar melaksanakan 
yang dikehendaki oleh umat, yang terjadi dalam praktek sistem demokrasi. Khalifah dibai'at oleh umat berdasarkan Kitabullah dan Sunnah rasul-Nya agar ia melaksanakan hukum syara', bukan untuk melaksanakan apa yang dikehendaki oleh umat, hingga bila seandainya orang yang telah membai'atKhalifah tersebut keluar dari ketentuan syara' (memberontak, atau membangkang terhadap aturan syara'), Khalifah akan memerangi mereka sampai kembali lagi. ${ }^{75}$

\section{Kekuasaan di tangan umat.}

Di dalam sistem demokrasi, rakyat adalah sumber kekuasaan. Dengan alasan dapat saling mengontrol, dalam negara demokrasi terdapat pembagian kekuasaan legislatif (parlemen) sebagai pembuat undang-undang, eksekutif (kabinet) sebagai pelaksananya, dan yudikatif (kehakiman) sebagai pengadilan atas pelanggaran undangundang. Ide ini lahir ide di Eropa, saat kekuasaan gereja dan kerajaannya sangatdominan, tirani, dan sangat menyesengsarakan rakyat yang mencapai puncaknya terjadi pada revolusi Perancis. Konteks teori itu dalam kenyataan tidaklah demikian. Sebagai contoh, presiden diberi wewenang untuk memveto rancangan undang-undang yang telah diterima oleh Kongres, tetapi di pihak lain, veto ini dapat dibatalkan oleh Kongres dengan suara $2 / 3$ dari anggota majelis. ${ }^{76}$ Faktanya tidak jarang mereka yang menempati ketiga lembaga tersebut berasal dari partai yang sama. Karenanya, pembagian kekuasaan tidak menuju pada arah yang diharapkan.

Menurut analisa M. Dhiauddin Rais, bahwa kekuasaan umat (rakyat) dalam demokrasi Barat bersifat mutlak. Rakyatlah yang menetapkan undang-undang atau menghapuskannya dalam pelaksanaanya dillakukan oleh badan legislatif, Keputusankeputusan yang dikeluarkan menjadi hukum yang harus dilaksanakan dan ditaati, sekalipun hal itu melanggar moral atau bertentangan dengan kepentingan universal manusia. Dengan demokrasi misalnya, dapat mengumumkan perang demi mendapatkan kekuasaan atas bangsa lain, untuk menguasai pasar, menganeksasi suatu wilayah, untuk memonopoli ladang-ladang minyak, Demi tujuan itu, darah manusia ditumpahkan tanpa henti dan nyawa manusia dalam jumlah yang tak terhitung telah tercabut. Akhirnya, seluruh manusia merasakan nestapa demi tujuan itu. 
Dalam perspektif M. Dhiauddin Rais, bahwa dalam sistem Islam kekuasan umat (rakyat) tidak semutiak itu, tetapi terikat oleh syariat, yaitu agama Allah yang wajib dilaksanakan oleh setiap individu, sehingga seseorang tidak dapat berbuat sewenangwenang melampaui batas hukum yang ada. Hukum tersebut meliputi aturan yang terdapat dalam al-Qur'att dan as-Sunnah. Jika Islam telah mengakui adanya kedaulatan rakyat secara keseluruhan, yang merupakan salah satu dari sumber hukum, kedaulatan yang dimilikinya itu hams beriandaskan apa yang dibawa oleh al-Qur'an dan as-Sunnah, karena kedaulatan yang dimilikinya itu datang dari al-Qur'an dan as-Sunnah itu sendiri. Telah ditegaskan bahwa salah satu karakteristik aspirasi umat (rakyat) ini adalah tidak menyimpang dari kebenaran, atau tidak melenceng dari manhaj yang telah digariskan alQur'an dan as-Sunnah itu. Umat Islam harus berpegang pada aturan akhlak dan terikat dengan prinsip-prinsip Islam. ${ }^{77}$

Hampir identik dengan demokrasi, Islam juga memandang kekuasaan di tangan rakyat atau umat. Umatlah yang berhak memilih penguasa, bisa melalui sistem perwakilan (ahlul halli wal aqdi) atau pun pemilihan langsung. Tidak seorang pun dapat menjadi penguasa, kecuali telah dikehendaki umat, yang ditunjukkan dengan bai'at. Hanya saja, kekuasaan yang diberikan itu hanyalah untuk menjalankan syariat Islam (kedaulatan Allah) semata; bukan untuk menjalankan kedaulatan rakyat dalam paham demokrasi. Pemilu diadakan untuk memilih wakil rakyat dalam majelis syura untuk menyampaikan pendapat umat, tapi bukan untuk menetapkan hukum, atau untuk memilih khalifah bila sistem yang digunakan adalah pemilihan langsung. ${ }^{78}$

Menurut Taqiyuddin Al-Nabhani bahawa syara 'telah diangkat oleh Khalifah oleh orang-orang, di mana seorang khalifah hanya berkuasa melalui kesetiaan. Hujah bahawa 'telah membuat pelantikan khalifah oleh masyarakat sangat tegas dalam hadis mengenai kesetiaan. Dari Ubadah bin Shamit yang berkata:

"Kami telah mengambil Nabi Allah untuk setia mendengarkan dan mematuhi perintahnya, baik dalam situasi sukar dan senang, baik dalam situasi yang kita suka atau tidak suka". ${ }^{79}$

Dalam pandangan Taqiyuddin Al-Nabhani bahawa kesetiaan diberikan oleh orang-orang Islam kepada khalifah, bukan oleh khalifah kepada orang-orang Islam, kerana merekalah yang mengambil khalifah, mereka sebenarnya melantik khalifah 
sebagai pemerintah mereka.. Pada masa Khulafa al-Rasyidin telah terjadi pengangkatan Khalifah dengan cara mengambil bai'at dari tangan umat. Mereka juga tidak ada yang menjadi Khalifah, bila bukan dengan bai'at dari umat yang diberikan kepada mereka. ${ }^{80}$

Sedangkan tentang Khalifah memiliki kekuasan karena dibai'at adalah jelas dan tegas berdasarkan hadis-hadis at-tha'at (keharusan taat kepada imam) dan hadis-hadis kesatuan khilafah. Diriwayatkan dari Abdullah bin Amr bin Ash yang berkata:

ومن بايع فاعطاه صفقة يده وثمرة قلبه فليطعه ان استطاع فان جاء اخر يناز عه فاضربوا عتق الاخر Artinya: Sesiapa yang telah setia kepada seorang imam, maka dia telah memberikan tangan dan hati pertolongannya, hendaklah dia mematubinya jika dia mampu. Sekiranya orang lain mahu mengambilnya, maka potonglab kerongkong orang itu. ${ }^{81}$

Hadis ini memperikan penjelasan bahwa seorang imam mendapatkan kekuasaannya hanya dengan membai'atnya. Dari Nafi' yang berkata : "Abdullah bin Umar berkata kepadaku, aku mendengar Rasul bersabda:

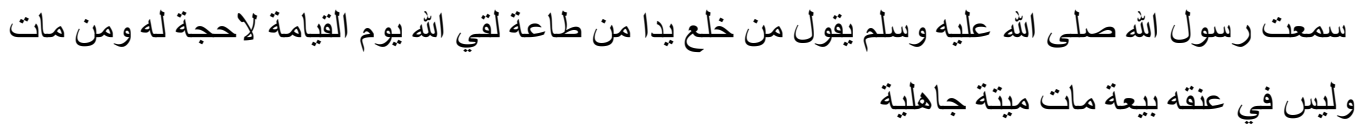

Artinya: Barangsiapa melepaskan tangannya dari ketaatan kepada Allah, 'dia akan menyerabkan kamu kepada Allah pada hari kiamat tanpa bukti, dan barangsiapa yang mati ketika di pundaknya tidak ada kesetiaan, maka dia akan mati dalam keadaan mati.. ${ }^{82}$

Hadis-hadis ini, menurut Taqiyuddin Al-Nabhani menunjukkan bahwa Khalifah mendapatkan kekuasaan semata-mata melalui bai'at. Allah telah mewajibkan untuk mentaati khalifah dengan setia. Ini kerana khalifah yang baru telah menerima khailfahnya dengan mengambil bai'at dan orang-orang wajib mematuhinya kerana dia adalah khalifah yang benar-benar telah setia. Oleh itu, khalifah benar-benar memperoleh kekuasaan dari tangan orang-orang dengan kesetiaan orang kepadanya. Maka kepatuhan umat mesti diberikan kepada mereka yang mereka percayai. ${ }^{83}$ Mengangkat satu Khalifah hukumnya fardlu 
Berbicara mengenai kepemimpinan kaum muslimin, tampaknya Al-Mawardi dan Taqiyudin Al-Nabhani memiliki pendapat yang sama. Al-Mawardi berpandangan bahwa mengangkat satu Khalifah hukumnya fardlu bagi seluruh kaum muslimin. Pandangan tersebut sejalan dengan persepsi Taqiyuddin Al-Nabhani yang juga berpandangan berpandangan bahwa jika dua kepala negara diangkat di dua wilayah dari negara Islam, kepemimpinan keduanya tidak sah karena umat islam tidak boleh mempunyai dua kepala negara dalam satu waktu meskipun ada pendapat menyimpang dan membolehkannya. ${ }^{84}$

Dalam mendukung argumentasinya, Imam al-Mawardi mengemukakan bahwa jabatan itu jatuh kepada orang yang lebih dahulu dibai'at dan diberikan jabatan; seperti halnya dua orang wali dalam menikahkan seorang wanita; jika keduanya menikahkan wanita itu dengan dua orang yang berbeda., nikah itu hanya sah bagi orang yang pertama melaksanakan akad nikah. Jika orang yang iebih dahulu dibai'at telah diketahui, jabatan itu diberikan kepadanya dan orangyang didahului harus menyerahkan wewenang itu kepadanya serta turut melakukan bai'at kepadanya. Akan tetapi, jika akad itu terjadi pada keduanya secara bersamaan, tidak ada yang lebih dahulu dari yang lain, kedua akad itu batal dan akad baru kembali diiakukan bagi salah satu dari keduanya atau orang selain keduanya. Jika salah satu bai'at dari keduanya lebih dahulu, namun tidak diketahui siapa yang lebih dahulu dari keduanya, masalah ini menunggu penelitian selanjutnya. ${ }^{85}$

Menurut Taqiyuddin Al-Nabhani bahwa hukum fardlu tersebut tersebut sebenarnya telah ditetapkan di dalam hadis-hadis tentang bai'at. Dari Nafi dan dari Abdullah IbnuUmar, Rasulullah menjelaskan siapa yang mati tanpa ada bai'at terhadap imam, matinya adalah jahiliyah. ${ }^{86}$

Wajhul Istidlal (suatu bentuk makna yang dapat diambil sebagai bukti) melalui hadis ini adalah bahawa Rasulullah telah mewajibkan setiap Muslim untuk setia kepada seorang Khalifah di bahunya, tidak mewajibkan setiap orang Islam untuk mengambil Khalifah. Oleh itu, yang wajib ada adalah adanya bai'at di bahu setiap Muslim, yakni adanya khalifah yang dengan demikian di bahu setiap muslim ada bai'at. Kerana adanya khalifah itulah yang menyebabkan setiap muslim memiliki bai'at, baik kerana dia secara langsung berjanji atau tidak.

Sedangkan Khalifah itu harus satu orang, disandarkan kepada hadis yang diriwayatkan dari Abi Said al-Khudri dari Nabi Saw menjelaskan jika diangkat dua orang 
khalifah, bunuhlah yang terakhir. Apabila dibai'at dua orang Khalifah, maka bunublah yang terakbir dari keduanya. ${ }^{87}$ Hadis ini menegaskan bahwa kaum muslimin diharamkan untuk memiliki Khalifah lebih dari satu orang.

\section{Khalifah berhak mengadopsi hukum}

Khalifah selaku kepala negara adalah pemimpin umat Islam yang dipilih dan dibai'at umat. la adalah wakil umat dalam melaksanakan syariat Allah, la berhak mentabanni (melegalisasi) hasil ijtihad seorang mujtahid untuk menjadi hukum syara' bagi kaum muslimin. la berhak pula menetapkan aturan dalam persoalan muamalat yang mubah (sistem administrasi, peraturan lalu lintas, dan sebagainya) demi kemaslahatan kaum muslimin. Selain itu, ia mengawasi pelaksanaan syariat Islam dan menghukum orang yang melanggarnya. ${ }^{88}$

Menurut Taqiyuudin Al-Nabhani bahwa bahwa hanya Khalifah yang berhak melakukan mentabanni (adopsi) terhadap hukum-hukum syara'. Pernyataan ini ditetapkan berdasarkan dalil ijma sahabat. Ijma sahabat telahmenetapkan bahwa hanya Khalifah yang berhak untuk mengadopsi hukum-hukum syara'. ${ }^{89}$

Menurut Taqiyuddin Al-Nabhani, jika salah satu pilar-pilar tersebut tidak ada, maka pemerintahannya tidak bisa disebut pemerintahan Islam, kecuali setelah menyempurnakan empat pilar ini seluruhnya. ${ }^{90}$

Dari uraian di atas, penulis memahami bahwa Sayyid Quthub dan Taqiyuddun alNabhani tidak setuju dengan Sistem pemerintahan yang ada sekarang ini. Antara lain :

a) Sistem Pemerintahan Republik. Kerana sistem pemerintahan dalam bentuk republik berdiri di atas tonggak demokrasi, kedaulatannya berada di tangan rakyat. Adalah orang-orang yang kemudian berhak memerintah dan membuat peraturan, termasuk orang-orang yang kemudian berhak menentukan seseorang menjadi penguasa, dan pada masa yang sama hak untuk memberhentikannya. Rakyat juga berhak membuat peraturan dalam bentuk undang-undang dan perundangan dasar, termasuk hak untuk menghapus, mengganti dan mengubahnya. ${ }^{91}$ 
b) Sistem Pemerintahan Imperial. Ini kerana sistem ini tidak menganggap ras yang sama antara satu sama lain dalam hal penguatkuasaan undang-undang di dalam kerajaan. Dalam sistem kekaisaran, ia telah memberikan hak istimewa di bidang pemerintahan, keuangan, dan ekonomi di wilayah tengah. ${ }^{92}$ Menurut Sayyid Qutub dan Taqiyuddin Al-Nabhani, sistem Islam sangat berbeza dengan sistem kekaisaran. Dalam sistem Islam, tidak ada daerah yang menjadi wilayah penjajah, atau tanah untuk eksploitasi dan tanah yang subur yang selalu dikeruk untuk wilayah tengah. Kerana kawasan-kawasan ini masih dianggap satu unit, walaupun ada jarak antara satu wilayah dengan ibu kota wilayah Islam. Begitu juga masalah kepelbagaian kaum warganya. Ini karena setiap wilayah dianggap memiliki hak yang sama dengan wilayah pusat, atau wilayah lain, wewenang pejabat pemerintahnya, sistem dan perundangannya sama seperti semua wilayah lain. $^{93}$

c) Sistem pemerintahan beraja. Sistem monarki, pemerintah menerapkan sistem pewarisan atau putera mahkota, takhta kerajaan akan diwarisi oleh putera mahkota, dan orang tuanya, seolah-olah mereka mewarisi harta pusaka. Kerajaan Islam tidak pernah memberikan khalifah atau imam apa-apa kekhususan dalam bentuk hak istimewa atau hak istimewa. Khalifah tidak mempunyai hak selain hak yang sama dengan hak orang biasa.

d) d) Sistem Pemerintahan Persekutuan. Sistem pemerintahan adalah dalam bentuk persekutuan yang membahagi wilayahnya menjadi autonomi mereka sendiri dan bersatu dalam pemerintahan secara umum. Maka sistem ini ditolak oleh Sayyid Qutub dan Taqiyuddin Al-Nabhani. Sebabnya ialah sistem pemerintahan Islam adalah sistem kesatuan, yang merangkumi seluruh negara. Aset semua kawasan di negara Islam dianggap satu.

\section{KESIMPULAN}

Adapun konsep pemikiran khilafah menurut Sayyid Quthb dan Taqiyuddin AlNabhani tentang penguasa (khalifah), sistem pemerintahan islam, pilar-pilar pemerintahan islam : 
1) Pemikiran konsep khilafah menurut Sayyid Quthb tentang penguasa, sistem pemerintahan islam, pilar-pilar pemerintahan islam:

a) Pemikiran konsep penguasa/khalifah menurut Sayyid Quthb bahwa orang yang menjadi penguasa (Khalifah) karena pilihan sempurna kaum muslimin, yang bertindak dalam kebebasan mutlak, namun orang tersebut mendapat otoritas karena terus menerus menerapkan hukum Tuhan. Kalau hal ini gagal, maka penguasa tersebut dapat dipecat bila umat muslimin tidak lagi puas dengannya. Pernyataan ini memberikan isyarat supaya umat menyingkirkan penguasa yang tidak lagi memenuhi fungsinya (penguasa zhalim).

b) Sistem pemerintahan islam menurutnya, pemerintahan yang paling bagus adalah pemerintahan Supra Nasional (kesatuan seluruh dunia islam). Dalam sistem ini, wilayah Negara meliputi seluruh dunia Islam dengan pemusatan kuasa dalam pemerintahan pusat. Yang dikendalikan berdasarkan prinsip persamaan penuh antara semua umat Islam di seluruh dunia Islam, tanpa ada fanatik perkauman dan wilayah. Mengenai penggunaan potensi pendapatan yang dimiliki oleh wilayah tersebut, diutamakan untuk digunakan untuk kepentingan wilayah itu sendiri, dan jika masih ada lagi, dana tersebut akan disetorkan ke Bait al-Mal atau perbendaharaan pemerintah pusat sebagai harta bersama umat Islam yang akan digunakan untuk kepentingan bersama bila diperlukan.

c) Pilar-pilar pemerintahan islam dibentuk diatas tiga pilar utama yaitu keadilan penguasa, ketaatan rakyat, permusyawaratan antara rakyat dengan penguasa.Ketiga pilar tersebut merupakan bagian pokok dalam konsep politik Islam. Ketiganya tidak bisa berdiri sendiri namun saling mendukung antara satu dengan yang lain.

2) Pemikiran konsep khilafah menurut Taqiyuddin Al-Nabhani tentang penguasa, sistem pemerintahan islam, pilar-pilar pemerintahan islam :

a) Idea konsep pemerintah / khalifah menurut Taqiyuddin Al-Nabhani adalah orang yang mewakili rakyat dalam urusan pemerintahan dan kekuasaan dan dalam melaksanakan undang-undang syara '. Islam telah menjadikan pemerintahan dan kekuasaan menjadi milik umat, ummah 
mewakili seseorang untuk menjalankan urusan ini - sebagai wakil mereka. Bahkan Allah juga mewajibkan umat untuk menerapkan hukum syara 'secara keseluruhan.

b) Sistem pemerintahan Islam menurut Taqiyuddin Al-Nabhani bahawa sistem pemerintahan Islam adalah khalifah. Menurut Al-Nabhani, dalam sistem pemerintahan Islam tidak ada menteri atau kementerian dengan kepala negara seperti dalam konsep demokrasi, yang memiliki pengkhususan dan jabatan tertentu. Dia menjelaskan bahawa dalam sistem pemerintahan Islam hanya ada mu'awin (pembantu ketua negara) yang selalu diminta pertolongan oleh ketua negara. Tugas mereka adalah untuk membantu ketua negara dalam tugas-tugas pemerintah. Mereka berdua adalah pembantu dan pelaksana. Ketika ketua negara memimpin mereka, ketua negara memimpin mereka bukan dalam kapasitas mereka sebagai perdana menteri atau ketua cabang eksekutif, tetapi hanya sebagai penguasa negara. Kerana dalam Islam tidak ada menteri kabinet yang ditugaskan untuk membantu khalifah dengan memiliki kekuatan tertentu. Oleh itu, mu'awin hanya menjadi pembantu khalifah untuk menjalankan kuasanya.

c) Rukun pemerintahan Islam menurut Taqiyuddin Al-Nabhani adalah empat rukun: 1). Kedaulatan di tangan syara ', 2). Kuasa adalah milik rakyat, 3). Untuk melantik seorang khalifah undang-undang adalah fardlu bagi semua umat Islam, dan 4). Hanya Khailfah yang berhak membuat tabanni (adopsi) hukum syara '. 5) Khalifah berhak membuat perlembagaan dan semua undang-undang lain.

3) Adapun perbedaan konsep khilafah menurut Sayyid Quthub dengan Taqiyyuddin al-Nabhani (Hizbuttahrir)tentang penguasa, sistem pemerintahan islam, pilar-pilar pemerintahan islam.

a) Menurut Sayyid Quthub, apabila penguasa gagal, maka penguasa tersebut dapat dipecat bila umat muslimin tidak lagi puas dengannya. Pernyataan ini memberikan isyarat supaya umat menyingkirkan penguasa yang tidak lagi memenuhi fungsinya (penguasa zhalim). Lain halnya dengan pendapat Taqiyuddin al-Nabhani. Seorang Amirul mukminin (Khalifah), 
meskipun bertanggung jawab dihadapan umat dan wakil-wakilnya, namun umat dan wakilnya tidak berhak untuk memberhentikannya. Khalifah juga tidak akan diberhentikan, kecuali apabila menyimpang dari hukum syara'. Adapun yang menentukan pemberhentiannya adalah hanya mahkamah Mazhalim.

b) Sistem pemerintahan islam menurut Sayyid Quthub tidak mempersoalkan sistem pemerintahan apapun sesuai dengan sistem kondisi masyarakat, namun pemerintahan ini bercirikan penghormatan pada superemasi hukum Islam (syari'ah). Sedangkan Menurut Taqiyuddin Al-Nabhani bahwa sistem pemerintahan Islam adalah khilafah.

c) Pilar-pilar pemerintahan islam menurut Sayyid Quthub dan Taqiyyuddin al-Nabhani, poin tiga bagian a dan b pada kesimpulan diatas ialah: 1). Sayyid Quthub: a). Keadilan penguasa; b). Ketaatan rakyat; c). Permusyawaratan antara rakyat dengan penguasa. 2). Taqiyyuddin alNabhani: a). Kedaulatan di tangan syara; b). Kekuasaan milik umat; c). Mengangkat satu Khalifah hukumnya fardlu bagi seluruh kaum muslimin; d). Hanya Khailfah yang berhak melakukan tabanni (adopsi) terhadap hukum-hukum syara; e). Khalifah yang berhak membuat undang-undang dasar dan semua undang-undang yang lain.

4) Adapun dasar-dasar hukum penetapan khilafah menurut Sayyid Quthub dan Taqiyyuddin al-Nabhani tentang penguasa, sistem pemerintahan islam, pilar-pilar pemerintahan islam:

a) Dasar-dasar hukum penetapan khilafah menurut Sayyid Quthub: 1). Penguasa, Qur'an Surah (2) al-Baqarah ayat 30; 2). Sistem Pemerintahan Islam, Qur'an Surah (24) an-Nur ayat 55; 3). Pilar-Pilar Pemerintahan Islam, Qur'an Surah (4) an-Nisa' ayat 58.

b) Dasar-dasar hukum penetapan khilafah menurut Taqiyyuddin al-Nabhani: 1). Penguasa, hadis riwayat Muslim dari Abu Said Al khudri, Hadits no. 1853 dan Muslim dari Abdullah Bin Amru Bin Ash, Hadis no. 1844; 2). Sistem Pemerintahan Islam, al-Qur'an surah an-Nisa'(4) ayat 59, an-Nisa'(4) ayat 65. Muslim, shahih Muslim,jilid, 3 hlm, 1459 dan 1480; 3). Pilar-Pilar 
Pemerintahan Islam al-Qur'an surah An-Nisa(3) ayat 65, dan Surah An-Nisa (3) ayat': 5.

\section{END NOTES}

${ }^{1}$ Al-Qur'an Surah al-Anbiya' (21) ayat 107:

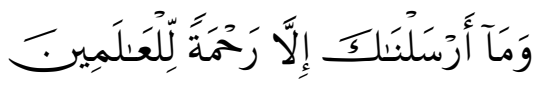

Dan tiadalah kami mengutus kamu, melainkan untuk (menjadi) rahmat bagi semesta alam.

${ }^{2}$ Arief B. Iskandar, Materi Dasar Islam; Islam mulai akar bingga daun, (Bogor: alAzhar Press, 2015), hlm. 105 hlm. 13

${ }^{3}$ Departemen Agama RI, al-Qur'an dan terjemahnya, (Jakarta: PT Intermasa, 2011),

${ }^{4}$ Harun Nasution, Pembaharuan Dalam Islam: Sejarah Pemikiran dan Gerakan, (Jakarta: Bulan Bintang, 2015), hlm. 154

${ }^{5}$ Munawir Sjadzali, Islam dan Tata Negara : Ajaran, Sejarah dan Pemikiran, Jakarta: UI Press, 2013), hlm. 111-112.

${ }^{6}$ Munawir Sjadzali, Islam dan Tata Negara, hlm. 1-2

${ }^{7}$ Abdul Wahab khallaf, Politik Hukum Islam, terj. Zainuddin Adnan. (Yogyakarta: Tiara Wacana, 2014), hlm. 11

${ }^{8}$ Munawir Sjadzali, Islam dan Tata Negara, hlm. 1-2.

${ }^{9}$ Pada awal November 1922, Kemal Attaturk telah menghapuskan kesultanan, namun ia masih mempertahankan kekhifaan. Pada tanggal 1922, Wahiduddin (Muhammad VI) diberhentikan dari jabatan kekhalifaan. Sebagai penggantinya, dibai'atlah Abdul Majid. Pada tanggal 2 Maret 1924, khalifah resmi dibekukan. Sejak saat itulah, untuk pertama kalinya dalam sejarah kepemimpinan Islam, kaum musliminhidup tanpa kekhalifaan sampai kini Lihat Abdul Majid Abdussalam al-Muhtasib, Visi dan Paradigma Tafsir al-Qur'an Kontempoler, terj. Mohammad Magfur Wachid, (Bangil: al-Izza, 1997), hlm. 24

${ }^{10}$ Arief B. Iskandar, Materi Dasar Islam, hlm. 105.

Sempurna dalam arti mengatur seluruh interaksi yang terjadi antara manusia dengan Allah berkenaan tentang ibadah, manusia dengan seama manusia berkenaan dengan tentang muamalah termaksud didalamnya tentang masalah pemeritahan, manusia dengan dirinya sendiri, berkenaan akhlak, makanan,minuman.

${ }^{11}$ Taqiyuddin al- Nabhani, Nizham al- Isalm, (Beirut: Dar al-Ummah, 2001), hlm.

\footnotetext{
${ }^{12}$ Taqiyuddin al- Nabhani, Niz̧ham al- Isalm, hlm. 69

${ }^{13}$ Arief B. Iskandar, Materi Dasar Islam, hlm. 105
} 
${ }^{14}$ Departemen Agama RI, al-Qur'an dan terjemahnya, hlm. 128

${ }^{15}$ Al-Khalidi, Qawaid Nið̧am Al-Hukmi, (Amman: Al-Maktabah Al-Muhtasib, 1983), hlm. 239

${ }^{16}$ Hafidz Abdurrahman, Diskursus Islam Politik dan spritual, (Bogor: Al-Azhar Press, 2014), cet. 1, hlm. 229

${ }^{17}$ Taqiyuddin al-Nabhani, Nizham al-Hukm, hlm. 32-33

${ }^{18}$ Sayyid Quthub, Fi Zhilalil Qur'an, terj. BEY Arifin dan Jamaluddin Kafie, (Surabaya: Bina Ilmu, 2012), Jilid 3, hlm. 413

${ }^{19}$ Sayyid Quthub, Fi Zhilalil Qur'an, jilid 7, hlm.72.

${ }^{20}$ Sayyid Quthub Al-Adalah Al-Ijtima'iyyah fi Al-Islam (Kairo-Darul Kitab Al'Arobi 1967), cet ke 7, hlm. 35

${ }^{21}$ Sayyid Quthub, Fi Zhilalil Qur'an, hlm 451

${ }^{22}$ Departemen Agama RI, al-Qur'an dan terjemahnya, hlm. 79

${ }^{23}$ HR Bukhari dan Muslim

${ }^{24}$ Sayyid Quthub, Fi Zhilalil Qur'an, jilid 2, hlm. 292-293

${ }^{25}$ Sayyid Quthub, Fi Zhilalil Qur'an, hlm. 293

${ }^{26}$ Departemen Agama RI, al-Qur'an dan terjemahnya, hlm. 354.

${ }^{27}$ Sayyid Quthub, Fi Zhilalil Qur'an, Jilid 9, hal.205.

${ }^{28}$ Departemen Agama RI. al-Qur'an dan terjemahnya, hlm. 343

${ }^{29}$ Departemen Agama RI. al-Qur'an dan terjemabnya, hlm. 498

${ }^{30}$ Sayyid Quthb, al-'Adalah al-Ijtia'iyyah fi al-Islam, hal.123.

${ }^{31}$ Effendy, Bahtiar, Teologi Baru Politik Islam. Pertautan Agama, Negara dan Demokrasi. Galang Press 2011, hlm. 23

${ }^{32}$ Departemen Agama RI, al-Qur'an dan terjemabnya, hlm. 553

${ }^{33}$ Sayyid Quthub, Tafsir fi zilalil Qur'an, dibawah naungan Al Qur'an, Jilid II, penerjemah Yusoff Zaky Haji Yacob, (Kuala Lumpur: Pustaka Aman Press Sdn Bhd, 2010), hlm. 450.

${ }^{34}$ Sayyid Quthub, al-'Adalah al-Ijtia'iyyah fi al-Islam, hlm. 124-125.

${ }^{35}$ Sayyid Quthub, al-'Adalah al-Ijtia'iyyah fi al-Islam, hlm. 125

${ }^{36}$ Demokrasi secara etimologis terdiri Dari dua kata yang berasal Dari bahasa Yunani, yaitu "demos" yang berarti rakyat atau penduduk suatu tempat dan "cratein" atau "cratos" yang berarti kekuasaan/kedaulatan, pemerintahan. Jadi "demos-cratein" atau "demos-cratos" (demokrasi) adalah kekuasaan atau kedaulatan rakyat, kekuasaan tertinggi berada dalam keputusan rakyat, rakyat berkuasa, pemerintahan rakyat dan kekuasaan oleh rakyat. Miriam Budiardjo, Demokrasi di Indonesia: Demokrasi Parlementer dan Demokrasi Pancasila,(Jakarta: Gramedia Pustaka Utama, 2016), hlm. 50 Lihat: pula Dorothy Pickles, Democracy (London: B.T. Batsford Ltd, 1970), hlm. 10-11 dan R. Siti Zuhro, "Demokrasi: Suatu Tinjanan Teoritis", Jurnal Ilmu Politik (Jakarta: AIPI, LIPI dan Gramedia Pustaka Utama, 2013), hlm. 32. 
${ }^{37}$ Sayyid Quthub, al-'Adalah al-Ijtia'iyyah fi al-Islam, hlm. hlm. 129-133.

${ }^{38}$ Musdah Mulia, Negara Islam: Pemikiran Politik Husain Haikal, hlm.110.

${ }^{39}$ Wahyudi Kumorotomo, Etika Administrasi Negara, hlm. 20.

${ }^{40}$ Sayyid Quthub, al-'Adalah al-Ijtia'iyyah fi al-Islam, hlm. 101

${ }^{41}$ Syariat Islam dapat dipaham isebagai manhaj rabbani.Secara umum konsep islam adalah konsep yang rabbani. Menurut Qutb konsep robbani adalah yang dating dari Allah dengan membawa segala karakteristik tersendiri, sehingga ia merupakan konsep yang esensinya tidak berkembang tetapi manusialah dalam kerangkanyadan meningkat di dalam memahami dan menggapnya. Manusia akan tetap berkembang dan meningkat, tumbuh dan maju, sedangkan kerangka ini akan selalu mencakupnya dan konsep rabbani akan selalu membimbingnya; sebab sumber yang menciptakan konsep iniadalah juga sumber yang menciptakan manusia. Sayyid Quthub, Karakteristik Konsepsi Islam,terj. Muzzaki, (Bandung: Pustaka, 2010), hlm. 47.

${ }^{42}$ Annim, Muqaddimah Dustur, (Beirut: Darul Ummah, 2015), hlm.124

${ }^{43}$ Taqiyuddin Al-Nabhani, Nidhom al-Hukmi fi al-Islam, (Beirut: Dar al-Ummah, 1996), hlm. 51

${ }^{44}$ Muslim, Shobih Muslim , Jilid III, (Qahirah: Dar al-Ummah, 1991), Hadits no. 1853, Kitab Imarah, Bab Idza Buyi'a li Kholifataini, hlm. 1470

${ }^{45}$ Muslim, Shobih Muslim , Hadis no. 1844,

${ }^{46}$ Taqiyuddin Al-Nabhani, Nidhom al-Hukmi fi al-Islam, (Beirut: Dar al-Ummah, 1996), hlm. 51

${ }^{47}$ Taqiyuddin Al-Nabhani, Asy-Syakhshiyyah al-lslamiyyah, (Beirut: Dar al-Ummah, 2013), cet. 5, hlm. 31

${ }^{48}$ Departemen Agama RI, al-Qur'an dan terjemabnya, hlm. 146

${ }^{49}$ Taqiyuddin Al-Nabhani, Asy-Syakhshiyyah al-lslamiyyah hlm. 31

${ }^{50}$ Departtemen agama RI, al-Qur'an dan terjemahnya, hlm. 128

${ }^{51}$ Bukhari, Shahih Bukhari, jilid 3, (Beirut: Dar al-Fikr, 1995), hlm. 89, Hadist no. 4424,Kitab al- Maghozi, Bab Kitabi al-Nabi ila Kisra.

${ }^{52}$ At-Tirmidzi, Al-Jami' al-Shabih, (Beirut: Dar al-Fikri, 1998), Juz 4, hlm. 24, Hadis no.1423,

${ }^{53}$ Bukhari, Shahih Bukhari, hlm. 287, Hadis no.7210, Kitab al-Ahkam, Bab Bai'ati al-Shagir

${ }^{54}$ Taqiyuddin Al-Nabhani, Asy-Syakhshiyyah al-lslamiyyah, Juz II, hlm. 32

${ }^{55}$ Taqiyuddin Al-Nabhani, Asy-Syakhshiyyah al-lslamiyyah, Juz II, hlm. 32

${ }^{56}$ Al-Qur'an surah at-Thalaq (65) ayat: 2 


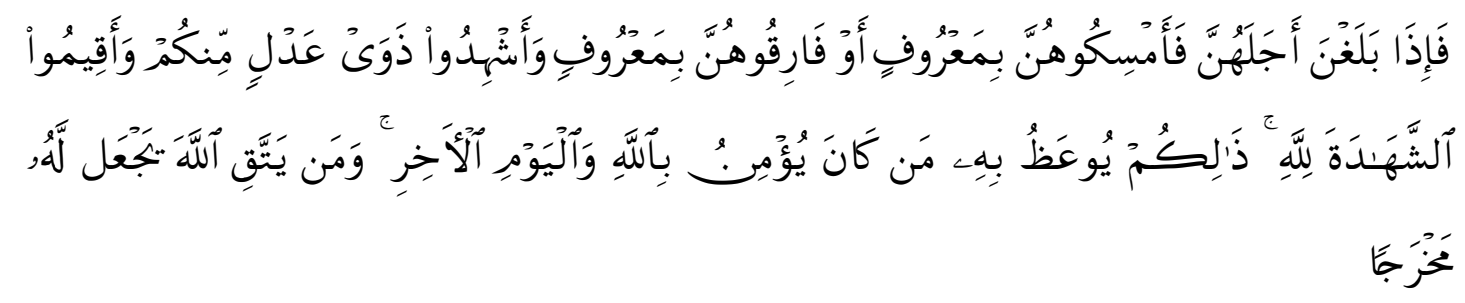

Apabila mereka telah menghampiri akhir iddah mereka, maka baiklah mendamaikan mereka atau biarkan mereka berjalan dengan baik dan saksikannya dengan dua saksi yang hanya ada di antara kamu, dan kamu harus menegakkan kesaksian ini kerana Allah. Inilah cara orang-orang yang beriman kepada Allah dan Akhirat diajar. barangsiapa takut kepada Allah, pasti dia akan memberikan jalan keluar baginya.

${ }^{57}$ Taqiyuddin Al-Nabhani, Asy-Syakhshiyyah al-lslamiyyah, Juz II, hlm. 33

58Taqiyuddin Al-Nabhani, Asy-Syakhshiyyah al-lslamiyyah, Juz II, hlm. 33

${ }^{59}$ Menurut M. Dhiauddin Rais bahwa Laqab (gelar) khalifah awal penyebutannya adalah kepada Abu Bakar r.a. ketika terpilih setelah bai'at di Saqifah bani Sa'idah, untuk menggantikan Rasulullah Saw dalam memimpin umat Islam dan memelihara kemaslahatan mereka.

60Taqiyuddin Al-Nabhani, Asy-Syakhshiyyah al-lslamiyyah, Juz II, hlm. 32.

${ }^{61}$ Menurut Taqiyuddin Al-Nabhani, jabatan kenabian berbeda dengan jabatan khilafah. Sebab, kenabian adalah jabatan llahiyah yang diberikan Allah kepada siapa saja yang Dia dikehendaki. Sedangkan jabatan khilafah merupakan jabatan basyariah (jabatan yang di oleh manusia), dimana kaum muslimin bisa membai'at siapa saja yang mereka kehendaki. Lihat Taqiyuddin Al Nabhani, Niz̧ham al-Hukm, hlm. 33

${ }^{62}$ Yusuf Qardhawi, Mm Fiqh Daulah, hlm. 80-82.

${ }^{63}$ Taqiyuddin Al-Nabhani, Niæham al-Hukm, hlm. 32-33

${ }^{64}$ Taqiyuddin Al-Nabhani, Nizham al-Hukm, hlm. 33

${ }^{65}$ Sistem kenegaraan Islam (Daulah Khilafah) adalah suatu kenyataan hukum dan sejarah kaum muslimin. Lihat Taqiyuddin Al-Nabhani, Sistem, hlm, 74.

${ }^{66}$ Taqiyuddin Al-Nabhani, Nizham al-Hukm, hlm. 35

${ }^{67}$ Taqiyuddin Al-Nabhani, Nizham al-Hukm, hlm. 36.

${ }^{68}$ Miriam Budiardjo, Dasar-Dasar llmu Politik, Jakarta: Gramedia Pustaka Utama, 1998), hlm. 173. Oleh J. J. Rosseau, peletak teori kedaulatan rakyat, disebut Volonte Generate atau General Will

${ }^{69}$ J. Shklar, Men and Citizens: Rosseau's Social Theory, (London: Cambridge University Press, 1969), hlm. 3-8.

${ }^{70}$ Pendapat ini senada dengan Abdul Qadim zalum yang memandang bahwa kedaulatan hanya ditangan Allah (as-Siyasah li asy-Syari'), bukan milik rakyat. Hal ini berarti yang memiliki kehendak tertinggi adalah hanya Allah Rabb al-'alami. Abdul Qadim Zallum, Demokrasi Sistem Kufu, Terj. Hlm. 46-48.

${ }^{71}$ Abdul Qadim Zallum, Demokrasi Sistem Kufu, hlm. 50 
${ }^{72}$ Departeman agama RI, al-Qur'an dan terjemahnya, hlm. 129

${ }^{73}$ Departeman agama RI, al-Qur'an dan terjemahnya, hlm. 115

${ }^{74}$ Departeman agama RI, al-Qur'an dan terjemahnya, hlm.43

${ }^{75}$ Departeman agama RI, al-Qur'an dan terjemahnya, hlm.43

${ }^{76}$ Miriam Budiardjo, Dasar-Dasar llmu Politik, hlm. 153.

${ }^{77}$ Departeman agama RI, al-Qur'an dan terjemahnya, hlm.153

${ }^{78}$ Ismail Yusanto, Islam Ideologi; Refleksi Cendikiawan Muda, (Bangil: Al-lzzah, 1998), hlm. 83-84.

${ }^{79}$ Muslim, Shahih Muslim, Hadits no. 1709, Kitab Imarah, Bab Wujub Tha'atu alUmara, hlm. 1470

${ }^{80}$ Ismail Yusanto, Islam Ideologi, hlm. 51.

${ }^{81}$ Muslim, Shabih Muslim, Hadist no. 1844, Kitab Imarah, Bab Wujud Tha'atu al Umara hlm. 1472

${ }^{82}$ Muslim, Shabih Muslim, Hadist no. 1844, Kitab Imarah, Bab Wujud Tha'atu al Umara hlm. 1472

${ }^{83}$ Menurut Taqiyuddin Al-Nabhani, kenyataan ini menunjukkan bahwa kekuasaan di tangan umat. Sama halnya dengan dengan Rasulullah, meskipun Muhammad Saw adaiah Rasulullah, namun ia tetap saja mengambil bai'at dari tangan umat. Maksudnya adaiah bai'at untuk mendapatkan kekuasaan dan pemerintahan, bukan bai'at terhadap kerasulan. Nabi Muhammad telah mengambil bai'at tersebut, baik dari pria maupun wanita dan Rasul tidak mengambil bai'at dari anak-anak kecil yang belum baligh. Sebab, kaum muslimin yang mengangkat seorang Khalifah dan membai'at mereka dengan Kitabullah dan Sunnah Rasul-Nya, di samping Khalifah mendapatkan kekuasaan hanya dengan adanya bai'at tersebut, maka semuanya itu telah menjadi dalil yang tegas bahwa kekuasaan adaiah milik umat, dimana umat bisa memberikan kepada siapa saja yang dikehendakinya. Lihat lsmail Yusanto, Islam Ideologi, hlm. 53.

${ }^{84}$ Imam al-Mawardi, Al Hakam al-Sulthaiyah, hlm.23

${ }^{85}$ Imam al-Mawardi, Al Hakam al-Sulthaiyah, hlm.24

${ }^{86}$ Muslim, Shabih Muslim, Hadits no. 1851, Kitab Imarah, Bab Wujub Malazimah... hlm. 1478

${ }^{87}$ Muslim, Shabih Muslim, Hadits no. 1853, Kitab Imarah, Bab idza Buyi'a li Khalifataini, hlm. 1480

${ }^{88}$ Ismail Yusanto, Islam Ideologi, hlm. 84

${ }^{89}$ Ismail Yusanto, Islam Ideologi, hlm. 84

${ }^{90}$ Taqiyuddin Al-Nabhani, Nið̧ham al-Hukm, (Beirut: Dar al-Ummah, 1994), hlm. 46

${ }^{91}$ Taqiyuddin Al-Nabhani, Nið̧am al-Hukm, hlm. 33-34

${ }^{92}$ Taqiyuddin Al-Nabhani, Nizham al-Hukm, hlm. 34 


\section{DAFTAR PUSTAKA.}

Samarah, lhsan, Mafnum al-Adalah al-ijtima yahfi al-Fikd al-lslami al-Mu'ashir, terj. Mubammad Shiddiq al-Jawi, (Bogor Al-Azhar Press, 2013)

Abdul, Shalah, Fatah al-Khalidi,"Pengantar Memahami Tafsi FI Zhilalil Qur'an", Terj: Salapuddin Abu Sayyid, (Surakarta: Era Intermedia, 2011)

Abdurrahman al-Jaziri, Al-Figh 'ala al-Madrithib al-Arba'ah, (Beirut: Darul Fikr, 1999), Cetakan I, Juz V

Abdurrahman, Hafidz, Diskursus Islam Politik dan Spiritual, (Bogor: Al-Azhar Press, 2014)

Agama, Departemen RI, al-Qur'an dan terjemahnya, (Jakarta: PT Intermasa, 2011)

AI-Baghdadi, Abdurrahman, Mat bum aI-Khâlifah wa al-Khllâfah ft al-Hadhârah al-lslâmiyah, Majalah Al-Khilafah ai-islamiyah. No 1 Th I. Syaban 1415 H/januari 1995 M, (Jakarta: Ai-Markaz Ai-istitiratiji ii ai-Buhuts ai-isiamiyah, 2015)

Al- Nabhani, Taqiyuddin, Niæham al- Isalm, (Beirut: Dar al-Ummah, 2011)

Al-Khalidi, Mahmud Abdul Majid, Qawa'id Nið̧ham al-Hukm fi al-lslam, (Kuwait: Darui Buhuts al 'Ilmiyah, 1980)

Al-Khalidi, Qawaid Niz̧bam Al-Hukmi, (Amman: Al-Maktabah Al-Muhtasib, 1983)

Al-Nabahani, Taqiyuddin, Al-Sakhsiyah Al-Islamiyah, (Beirut: Dar al-Ummah, 2013)

Al-Nabhani Taqiyuddin, Muqaddimah ad-Dustur (t.tp: Min Mansyurat Hizb at-Tahrir, 1963)

Al-Nabhani, Taqiyuddin, Ad-Daulab Islamiyah, (Beirut: Dar al-Ummah, 1994)

Al-Nabhani, Taqiyuddin, Asy-Syakhshiyyah al-lslamiyyah, (Al-Quds: Min Mansyurat Hizb Al-Tahrir, 1953)

Al-Nabhani, Taqiyuddin, Dukhul aI-Mujtamaç, (Al-Quds: Hizb at-Tahrir, 1958)

Al-Nabhani, Taqiyuddin, Membangun Sistem Ekonomi Altematif Perspektif Islam, terj. Muhammad Maghfur W achid, (Surabaya: Risalah Gusti, 2016)

Al-Nabhani, Taqiyuddin, Muqaddimah ad-Dustur, (t.tp.: Min Mansyurat Hizb at-Tahrir, 1963), bab Khilafah

Al-Nabhani, Taqiyuddin, Nidhom al-Hukmi fi al-Islam, (Beirut: Dar al-Ummah, 1996)

Al-Naquib, Muhammad, al-Attas, Islam dan Sekulaifsme, terj. Karsidjo Djojosuwamo, (Bandung: Pustaka, 2011)

Al-Qurtubi, Al-Jami'lil Abkam Al-Qur'an, (Beirut: Dar al Kutub al-'Ilmiyyah,1993), Vol. 1

Al-Zuhaili, Wahbah, Fiqhu al-Islam wa adillatubu, (Damsyiq: Dar al-Fikri, 1985)

Anis, Ibrahim, Al-Muam Al-Wäs(th, (Kairo: Darul Ma'arif, 1972), Juz I

Annim, Muqaddimah Dustur, (Beirut: Darul Ummah, 2009), cet. 2

Ar-Rais, Dhiya'uddin, Islam dan Khalifah: Kritik Terbadap Buku Khilafah dan Pemerintahan Islam Ali Abdurraziq, terj. Afif Mubammad, (Bandung: Pustaka, 2015)

Ath-Thabari, Jami al-Bayan fi Ta'wil al-Qur'an, (Beirut: Dar al-Kutub al-'ilmiyyah, 1992), Juz I 
At-Tirmidzi, Al-Jami' al-Shahih,(Beirut: Dar al-Fikri, 1998), Juz 4

Azra, Azyumardi, Pemimpin Redaksi, Ensikolopedi Islam, (Jakarta: Ikhtiar baru van Hoeve, Edisi baru, 2015), jilid 6

Azra, Azyumardi, Pergulatan Politik Islam, (Jakarta: Paramadina, 2016)

Binder, Leonard, Islam Liberal: Keritik Terhadap Idiologi-Idiologi Pembangunan, alih bahasa: Iram Mutaqin (Yogyakarta: Pustaka Pelajar, 2011),

Budiardjo, Miriam, Dasar-Dasar llmu Politik, (Jakarta: Gramedia Pustaka Utama, 2014), Oleh J. J. Rosseau, peletak teori kedaulatan rakyat, disebut Volonte Generate atau General Will

Bukhari, Shahih Bukhari, (Beirut: Dar al-Fikr, 1995), jilid 3

Charles Tripp" Sayyid Quthub: Visi Politike" Dalam Para Perintis Zaman Baru Islam, Ali Rahmena (ed), terj. Ilyas Hasan, (Bandung:Mirzan, 2016)

Chirzin, Muhammad, Jihad Menurut Sayyid Qutb dalam Tafsir Zhila,(Solo: Era Intermedia, 2011)

Dalimunthe, Mawardi, Perbandingan Pemikiran Politik Islam Sayyid Qutbub dengan Taqiyuddin Al-Nabhani tentang Khilafah, UIN Suska Riau, 2016.

Eddin, Saad, Ibrahim, Krisis Elit dan Demokratisasi Dunia Arab, Islamika, (Bandung: Mizan, April-JuniI1997),No.4,

Effendy, Bahtiar, Teologi Baru Politik Islam. Pertautan Agama, Negara dan Demokrasi. (Bandung: Galang Press, 2011)

Iskandar, Arief B., Materi Dasar Islam; Islam mulai akar bingga daun, (Bogor: al-Azhar Press, 2015)

J. Shklar, Men and Citizens: Rosseau's Social Theory, (London: Cambridge University Press, 1969),

Khaldun, Ibnu, Tarikh Ibnu Khaldun; Al Muqaddimah (beriut : Dar al-Ilmiyah, t.th)

Khalil, Manna, Al- Qattan,” Studi Ilmu- Ilmu Qur'an”terj. Mudzakir AS Cet. 15, (Bogor: Pustaka LinteraAntar Nusa, 2012),

Kurnia, MR, Menjadi Pembela Islam, (Bogor: Al-Azhar Press, 2015)

Lewis, Bernard, Muslim Menemukan Eropa, terj. Ahmad Niamullah Muis, (Jakarta: Pustaka Firdaus, 2013)

Ma'shum, Ali dan Zainal Abidin Munawwir, Kamus Al-Munawnir Arab-Indonesia (Surabaya: pustaka progresif, 2012),

Majid, Abdul, Abdussalam al-Muhtasib, Visi dan Paradigma Tafsir al-Qur'an Kontempoler, terj. Mohammad Magfur Wachid, (Bangil: al-Izza, 2017)

Mawardi, al Ahkam Al-Sulthaniyah, (Beirut : Dar al Fikr,1960), cet. 1

Mughni, Syafiq A., Sejarah Kebudayaan Islam di Turki, (Jakarta: Logos, 2012)

Muhammad, ibn Abdurrahman ad-Dimasyqi, Rahmah al-Ummah fi Ikbtilaf al-A'immah, (Beirut: Darul Fikr, 1996), Cetakan I, 
Mulia, Musdah, Negara Islam: Pemikiran Politik Husain Haikal, (Jakarta: Media Press, 2010)

Muslim, Shabih Muslim, (Qahirah: Dar al-Hadits, 1991), jilid 3

Muslim, Shohih Muslim,(Qahirah: Dar al-Ummah, 1991), Jilid III,

Nasution, Harun, Pembaharuan Dalam Islam: Sejarah Pemikiran dan Gerakan, (Jakarta: Bulan Bintang, 2015)

Pendidikan, Departemen dan kebudayaan, Kamus Besar Bahasa Indonesia (Jakarta: Balai Pustaka, 2017)

Quthub, Sayyid, “Fi Zhilalil Qur'an Juz Pertama” terj. BEY Arifin dan Jamaluddin Kafie, (Surabaya: Bina Ilmu, 2012),

Quthub, Sayyi, Mengapa Saya Dihukum Mati? Pengakuan terakbir Sayyid Quthub terj Ahmad Jauhar Tanwiri. (Bandung: Mizan. 2013)

Quthub, Sayyid, Al-Adalah Al-Ijtima'iyyah fi Al-Islam (Kairo-Darul Kitab Al-'Arobi 1967) cet ke 7

Quthub, Sayyid, Fi al-Tarikh: Fikrotun wa Minhajuh, alih bahasa Nabhan Husein, Konsepsi Sejarah dalam Islam, (jakarta: Yayasan al-Amin, t.th.)

Quthub, Sayyid, Keadilan Sosial dalam Islam, terj Arief Mohammad, (Bandung, Pustaka, 2014)

Quthub, Sayyid, Tafisr fi Zhilalil Qur'an di bawah naungan al-Qur'an, terj. As'ad yasin, dkk, jilid 10 (Jakarta: Gema Insani Press, 2013)

Rahman, Fazlur, Islam, terj. Ahsin Mohammad, (Bandung: Pustaka, 2013)

Salim, K. Bahnasawi, "Butir-Butir Pemikiran Sayyid Qutbb Menuju Pembaruan Gerakan Islam" cet.I, Terj. Abd. Hayyi al-Kattani, dkk, (Jakarta: Gema Insani Press, 2013)

Samarah, Ihsan, Taqiyuddin al-Nabbani, Meneropong Perjalanan Spritual dan Da'wahnya (Bogor: Al-Azar Press, 2013)

Sjadzali, Munawir, Islam dan Tata Negara : Ajaran, Sejarah dan Pemikiran (Jakarta: UI Press, 2013)

Taj, Suha, Farouki, " Hizb at-Tahrir al-Islami, The Oxford Encycolopedia of The Modem Islamic World, (New York: Oxford University Press, 1995)

Wahab, Abdul, khallaf, Politik Hukum Islam, terj. Zainuddin Adnan. (Yogyakarta: Tiara Wacana, 2014)

Warson, Ahmad, Munawwir, Kamus AI-Munawwir, (Yogyakarta: PP. Al-Munawwfr Krapyak, 2014)

Yusanto, 1smail, Islam Ideologi; Refleksi Cendikiawan Muda, (Bangil: Al-lzzah, 1998) 